\title{
The wolf spider genus Artoria Thorell in Australia: new synonymies and generic transfers (Araneae, Lycosidae)
}

\author{
Volker W. Framenau \\ Department of Terrestrial Invertebrates, Western Australian Museum, Locked Bag 49, \\ Welshpool D.C., Western Australia 6986, Australia
}

\begin{abstract}
The Australian wolf spider species Artoria albopilata (Urquhart, 1893), comb. nov., Artoria gloriosa (Rainbow, 1920), comb. nov., and Artoria impedita (Simon, 1909), comb. nov. are redescribed and the male of Artoria cingulipes Simon, 1909 and the female of Artoria parvula (Thorell, 1877) are illustrated for the first time. Artoria versicolor (L. Koch, 1877), Lycosa ambrymiana Berland, 1938 and Lycosa naeviella (Roewer, 1951) are considered junior synonyms of Artoria berenice (L. Koch, 1877), comb. nov. Based on the original species description, Artoria pruinosa (L. Koch, 1877), comb. nov. is transferred from Dingosa Roewer, 1955.

Artoria paroula is recorded from Australia for the first time and updated distribution maps with considerable range extensions are provided for most other Australian species of Artoria (A. albopedipalpis Framenau, 2002; A. alta Framenau, 2004; A. avona Framenau, 2002; A. flavimana Simon, 1909; A. howquaensis Framenau, 2002; A. lineata (L. Koch, 1877); A. mckayi Framenau, 2002; A. quadrata Framenau, 2002; A. triangularis Framenau, 2002; A. ulrichi, Framenau, 2002.
\end{abstract}

\section{INTRODUCTION}

The wolf spider genus Artoria Thorell, 1877 currently includes 13 Australian species (Framenau, $2002 ; 2004)$. The genus appears to be widespread in south-east Asia and the Australasian region with probably more than 80 undescribed species in Australia alone (Framenau 2002). Vink (2002) recently recorded three new species from New Zealand. The palpal morphology of Artoria is unique within the Lycosidae, and a preliminary molecular analysis suggests that this genus forms a monophyletic clade with Anoteropsis Koch, 1877 and Notocosa Vink, 2002 (Vink et al., 2002). This is consistent with morphological evidence, in particular the presence of a unique basoembolic apophysis on the male pedipalp, a putative synapomorphy for this group. Artoria, as well as Anoteropsis and Notocosa, do not fit in any of the current wolf spider subfamilies defined by Dondale (1986), Alderweireldt and Jocqué (1993) or Zyuzin (1985, 1993).

Ludwig Koch $(1876,1877,1878)$ described 13 Australian species of wolf spiders based or partly based on material from what is known as the Bradley Collection. Three of these species conform. to the definition of the genus Artoria and are included here: $A$. pruinosa (L. Koch, 1877), comb. nov., $A$. berenice (L. Koch, 1877), comb. nov., and $A$. versicolor (L. Koch, 1877) (revised in Framenau (2002) and here considered a junior synonym of $A$. berenice). There has been some speculation about the whereabouts of Bradley's Collection. None of its material could be located at the Natural History Museum, London, the Museum für Naturkunde, Zentralinstitut der Humboldt-Universität, Berlin, or the Zoologisches Institut und Zoologisches Museum, Universität Hamburg, where most of L. Koch's material is housed. A previous assumption that some spiders lodged in the Macleay Museum, University of Sydney, was part of the original Bradley Collection, could not be confirmed after a visit to this museum (personal observation). Some of L. Koch's material, presumably including at least part of the Bradley Collection, had been transferred to the Museum of Breslau (today Wrockaw, Poland) before the Second World War (e.g., Baehr and Baehr 1987, p. 384). However, a recent list of L. Koch's spider material that survived the total destruction of Wroclaw during WWII does not include any of the species that were described from the Bradley Collection (W. Wesolowska, personal communication). With no evidence of the whereabouts of this collection, I consider all wolf spider types from this collection lost.

As part of a revision of the wolf spiders of Australia, the main purposes of this study are to rectify the generic placement of all currently misplaced known Australian species of Artoria, to describe unknown sexes of species considered in Framenau (2002), and to expand the distribution maps of currently known species based on my database of more than 15,000 records (over 40,000 specimens examined) of wolf spiders lodged in Australian and overseas institutions. This 
complements a previous review of the genus Artoria that focused on species represented in a wolf spider study of floodplains in the Victorian Alps (Framenau, 2002; Framenau et al., 2002).

Artoria now includes 22 species as follows:

A. albopedipalpis Framenau, 2002

Australia

A. albopilata (Urquhart, 1893), comb. nov. Australia

A. alta Framenau, 2004

Australia

(only male known)

A. avona Framenau, 2002

A. berenice (L. Koch, 1877)

Australia

Australia, New

Caledonia, Vanuatu

A. cingulipes Simon, 1909

Australia

A. flavimana Simon, 1909

Australia

A. gloriosa (Rainbow, 1920), comb. nov. Australia

A. hospita Vink, 2002

A. howquaensis Framenau, 2002

New Zealand

A. impedita (Simon, 1909), comb. nov.

Australia

A. lineata (L. Koch, 1877)

A. mckayi Framenau, 2002

A. palustris (Dahl, 1908)

A. paroula Thorell, 1877

Papua New Guinea

Australia, Sulawesi,

Philippines

A. pruinosa (L. Koch, 1877), comb. nov. Australia

A. quadrata Framenau, 2002

A. segrega Vink, 2002

A. separata Vink, 2002

A. taeniifera Simon, 1909

(only female known)

A. triangularis Framenau, 2002

A. ulrichi Framenau, 2002

Australia

New Zealand

New Zealand

Australia

Australia

Australia

Platnick (2004) listed a further three species $(A$. amoena (Roewer, 1960), A. maculatipes (Roewer, 1960) and A. lycosimorpha Strand, 1909, from Africa), however, these generic placements are incorrect or doubtful based on Roewer's (1960) original descriptions and illustrations (Framenau, 2002).

\section{MATERIAL AND METHODS}

Descriptions are based on specimens preserved in $70 \% \mathrm{EtOH}$. Internal female genitalia were prepared for examination by submersion in lactic acid at room temperature for $2 \mathrm{hrs}$. For clarity, the setae have been omitted from the illustrations of epigyna and male pedipalps. The morphological nomenclature follows Framenau (2002). All type material was examined unless otherwise stated. All measurements are in millimeters ( $\mathrm{mm}$ ).

\section{Abbreviations}

Measurements (adult spiders, if not otherwise stated): total length (TL), carapace length (CL) and width (CW), abdomen length (AL) and width (AW).

Eyes: anterior (AE), anterior median (AME), anterior lateral (ALE), posterior (PE), posterior median (PME), posterior lateral (PLE).

Australian States and Territories: Australian Capital Territory (ACT), New South Wales (NSW),
Northern Territory (NT), Queensland (Qld), South Australia (SA), Tasmania (Tas), Victoria (Vic), Western Australia (WA).

Collections: Australian Museum, Sydney (AM); Australian National Insect Collection, Canberra (ANIC); Natural History Museum, London (BMNH); International Rice Research Institute, Entomology Division, Manila (IRRI); Macleay Museum, University of Sydney (MMUS); Muséum National d'Histoire Naturelle, Paris (MNHP); Muséum National d'Histoire Naturelle, Troyes (France) (MNHT); Museo Civico di Storia Naturale 'Giacomo Doria', Genova (Italy) (MSNG); Museum Victoria, Melbourne (MV); Museum and Àrt Gallery of the Northern Territory, Darwin (NTMAG); Queensland Museum, Brisbane (QM); Queen Victoria Museum and Art Gallery, Launceston (QVMAG); South Australian Museum, Adelaide (SAM); Tasmanian Museum and Art Gallery, Hobart (TMAG); Western Australian Museum, Perth (WAM); Museum für Naturkunde, Zentralinstitut der Humboldt-Universität, Berlin $(\mathrm{ZMB})$; Zoologisches Institut und Zoologisches Museum, Universität Hamburg ( $\mathrm{ZMH}$ ).

\section{SYSTEMATICS}

\section{Family Lycosidae Sundevall, 1833}

Artoria Thorell, 1877

Artoria albopilata (Urquhart, 1893), comb. nov. (Figures 1A-E, 2)

Lycosa albo-pilata Urquhart, 1893: 123-125.Rainbow, 1911: 265.

Lycosa albopilata Urquhart.- Roewer, 1955: 271; Bonnet, 1957: 2632; McKay, 1973: 378; McKay, 1985: 74 .

\section{Types}

Syntypes of Lycosa albo-pilata Urquhart, 1893: Male and female, Tasmania (no exact location). Types considered lost. Not examined.

Syntype female of Lycosa expolita L. Koch, 1877, Queensland, Brisbane, $27^{\circ} 28^{\prime} \mathrm{S}, 153^{\circ} 01^{\prime} \mathrm{E}, \mathrm{MHNT}$ AR0825 (misidentification). Examined.

\section{Other Material Examined}

Australian Capital Territory: 4 males, Blundells Creek, $3 \mathrm{~km}$ E of Picadilly Circus, $35^{\circ} 22^{\prime} \mathrm{S}, 148^{\circ} 50^{\prime} \mathrm{E}$, December 1984, T. Weir, J. Lawrence, M.-L. Johnson, 850m (ANIC); 4 males, 1 female, same location, January 1985, T. Weir, J. Lawrence, Dressler, $850 \mathrm{~m}$ (ANIC); 7 males, Tidbinbilla Nature Reserve, $35^{\circ} 28^{\prime} \mathrm{S}, 148^{\circ} 52^{\prime} \mathrm{E}, 9$ March 1978, pitfall trap, P. Ormay, PO ref site 11, 2408m (AM KS13830); 7 males, same data, PO ref site 12, 2409m (AM KS13873). New South Wales: 1 female, Badja 
State Forest, Badja Fire Trail, 36 07'30'S, 149³1'37'E, 13 March 1999, pitfall trap, J. Tarnawski, S. Lassau, CBCR003-028, SE Forests Survey, site 2 (AM KS64405); 1 male, Badja State Forest, Peters Road, 3608'52'S, 149 32'09'E, 13 March 1999, pitfall trap, J. Tarnawski, S. Lassau, CBCR003-029, SE Forests Survey (AM KS64401); 1 male, Badja State Forest, Pollys Gully Road, 3606'39'S, 149²8'26"E, 14 March 1999, pitfall trap, L. Wilkie, R. Harris, H. Smith, CBCR003-095, SE Forests Survey (AM KS64394); 4 females, Badja State Forest, Rocky Range Fire Trail, 36 03'21' $\mathrm{S}$, 149²8'29''E, 14 March 1999, pitfall trap, J. Tarnawski, S. Lassau, CBCR003-031, SE Forests Survey (AM KS64407); 1 male, Badja State Forest, Tuross River Road, 36²' $31^{\prime \prime S}, 149^{\circ} 30^{\prime} 07^{\prime \prime} \mathrm{E}, 13$ March 1999, pitfall trap, L. Wilkie, R. Harris, H. Smith, CBCR003-091, SE Forests Survey, site 2 (AM KS64402); 1 male, Badja State Forest, Wiola Creek Fire Trail, 3605'24'S, 149³4'51'E, 13 March 1999, pitfall trap, J. Tarnawski, S. Lassau, CBCR003-026, SE Forests Survey, site 3 (AM KS86409); 4 females, 2 juv., Beaury State Forest, SW end of Rock Waterhole Road, $28^{\circ} 33^{\prime} \mathrm{S}, 1^{\circ} 2^{\circ} 19^{\prime} \mathrm{E}, 4$ February -9 April 1993, M. Gray, G. Cassis, 01CG, 530m (AM KS36135); 1 male, Beaury State Forest, Tooloom Scrub, $28^{\circ} 35^{\prime} \mathrm{S}, 152^{\circ} 22^{\prime} \mathrm{E}, 12$ December 1988 , pitfall trap, Smith, Hines, Pugh, Webber, Focal Peak Survey U.N.E., T 6, road in dry rainforest, sheltered slope, 600-900m (AM KS50956); 1 male, same data, T 8, Hoop Pine plantation, sheltered slope, 600900m (AM KS51276); 4 males, 1 juv., Bondi State Forest, $37^{\circ} 08^{\prime} \mathrm{S}, 149^{\circ} 09^{\prime} \mathrm{E}, 25$ October - 28 November 1980, Woodlot (Woodlot material) (AM KS45437); 1 female, same data 4 July 1980, 28 November 1980, 7 January 1981, Woodlot (Woodlot material) (AM KS45438); 38 males, 8 females, 1 female with eggsac, 5 juv., Bondi State Forest, $S$ of Bombala, $37^{\circ} 08^{\prime} S$, $149^{\circ} 09^{\prime} \mathrm{E}, 26$ January 1981, G. Gowing et al., WL 1, Div 1-7, 10, litter, open eucalypt forest (AM KS12046, KS12061, KS12066, KS12084, KS12095, KS12110, KS12114, KS12123, KS12128, KS12140); 2 males, 3 females, 2 juv., same data, 6 May 1980, WL 1, Div 5-7, 10, litter, open eucalypt forest (AM KS12153, KS12158, KS12198, KS12215); 3 males, 5 females, 4 juv., Bondi State Forest, S of Bombala, Woodlot 1, 37 08'S, $149^{\circ} 09^{\prime} \mathrm{E}, 1$ July 1981, G. Gowing et al., WL 1, Div 5, 7, 10 litter, open forest (AM AM KS11440, KS11478-9, KS11489, KS15188, KS15192); 206 males, 22 females, 19 juv., same data, 14 November 1980, WL 1, Div 2-10 eucalypt litter (AM KS11526, KS11531, KS11549, KS11559, KS11576, KS11587, KS11597, KS11610, KS11622, KS11636, KS11661, KS11709, KS11720, KS11742, KS11752, KS11761, KS11772, KS11784, KS11799, KS11802, KS11807, KS11814, KS11824, KS11833, KS11842, KS11856, KS11864, KS11878, KS11892, KS11903, KS11914, KS11999, KS12007, KS12025); 4 males, same data, 15 October 1980, WL 1, Div 8, litter, open forest (AM KS11334); 1 male, same data, 25 October 1980, WL 1 reference collection, WL 1, Div 8, litter, open forest (AM KS18064); 6 males, same data, 25 October 1980, WL 1, Div 7, 10 (AM KS15201-2); 1 female, Bondi State Forest, $\mathrm{S}$ of Bombala, Woodlot $1,37^{\circ} 08^{\prime} \mathrm{S}, 149^{\circ} 09^{\prime} \mathrm{E}, 31$ December 1979, pitfall trap, G. Gowing et al., WL 1 reference collection, WL 1, Div 8, litter, open forest (AM KS18065); 4 females, same data, 31 March 1981, G. Gowing et al., WL 1, Div 2, 4, litter, open eucalypt forest (AM.KS11406; KS11424); 3 males, Bondi State Forest, Woodlot 2, 37 $07^{\prime} \mathrm{S}, 149^{\circ} 08^{\prime} \mathrm{E}, 28$ November 1980, G. Gowing et al., WL2-PAUC 6, 7, 9 (AM KS69145, KS69154, KS69169); 1 male, same data, 28 October 1980, PAUC 9 (AM KS70268); 16 males, 2 females, same data, 31 December 1979, PAUC 5 (AM KS70203); 1 female, Boonoo State Forest, Boonoo Forest Drive, $1.8 \mathrm{~km}$ from $\mathrm{Mt}$ Lindesay Hwy, 28 ${ }^{\circ} 56^{\prime} \mathrm{S}, 152^{\circ} 06^{\prime} \mathrm{E}, 8$ February - 9 April 1993, M. Gray, G. Cassis, 09CG, 163A, 1060m (AM KS37001); 1 male, Cherry Tree North State Forest, $28^{\circ} 58^{\prime} \mathrm{S}, 152^{\circ} 15^{\prime} \mathrm{E}, 17$ December 1988 , pitfall trap, Smith, Hines, Pugh, Webber, Focal Peak Survey U.N.E., CT 4, dry rainforest, exposed slope, 300m (AM KS86191); 6 males, same data, CT 9, $>300 \mathrm{~m}$ (AM KS63740); 40 males, 1 female, Coolangubra State Forest, near Waratah Creek, $37^{\circ} 01 ' \mathrm{~S}, 149^{\circ} 23^{\prime} \mathrm{E}$, January 1984, pitfall trap, G. A. Webb, Plot 1314, 2/8/1 (RTU 12) (AM KS79632); 45 males, 3 females, same data, Plot 1314, 1/4/2 (RTU 12) (AM KS79631); 2 females, Kangaroo Creek State Forest, $1.5 \mathrm{~km}$ along Burns Road from junction with Kangaroo Creek Road, 3004'S, $152^{\circ} 52^{\prime} \mathrm{E}$, 4 February - 9 April 1993, M. Gray, G. Cassis, 64CR, 430m (AM KS39730); 1 female, Kosciusko National Park, Bogong Creek and Alpine Way, 36 12 'S, 148 $19^{\circ} \mathrm{E}$, 28 November 1994, pans, D. Bickel, wet sclerophyll, 500m (AM KS45823); 1 female, Mt Keira Fauna Reserve, Scout Camp, 34 $24^{\prime} \mathrm{S}, 150^{\circ} 51^{\prime} \mathrm{E}, 23$ November - 20 December 1978, pitfall trap, C. Horseman, new series trap 3, 1220m (AM KS2213); 1 male, Shooters Hill, 335' S, $149^{\circ} 52^{\prime} \mathrm{E}, 5$ July 1975, M. R. Gray (AM KS45150); 1 female, Spirabo State Forest, $0.5 \mathrm{~km} \mathrm{~N} \mathrm{3-way} \mathrm{intersection,} \mathrm{near} \mathrm{Five} \mathrm{Bull}$ Creek, 29¹8'S, 15206'E, 6 February - 9 April 1993, M. Gray, G. Cassis, 45CG, 1070m (AM KS36981); 3 females, Styx River State Forest, bottom end of Cliffs trail, ca. $1.3 \mathrm{~km}$ from Oxley Road, 30³3'54"S, $152^{\circ} 20^{\prime} 50^{\prime \prime} \mathrm{E}, 4$ February - 9 April 1993, M. Gray, G. Cassis, NE NSW NPWS Survey, 33BR, 1080m (AM KS35651); 1 female, Tallaganda State Forest, Rocky Pic Road, 35³6'46"S, 149²9'52'E, 15 March 1999, pitfall trap, J. Tarnawski, S. Lassau, CBCR003-035, SE Forests Survey, site 2 (AM KS64404); 1 female, same data, CBCR003-036, site 3 (AM KS64406). Queensland: 1 female, Blackbutt Range summit, $5 \mathrm{~km}$ E Benarkin, $26^{\circ} 52^{\prime} \mathrm{S}, 152^{\circ} 11^{\prime} \mathrm{E}, 24$ October - 24 November 1995, pitfall trap, G. Monteith, rainforest (QM S43821); 4 males, 2 females, 1 juv., Boat 
Mountain, summit, $26^{\circ} 09^{\prime} \mathrm{S}, 151^{\circ} 59^{\prime} \mathrm{E}, 29$ September - 15 December 1994, pitfall trap, G. Monteith, vine scrub (QM S37818; S61961); 1 male, same data, 4 December 1994 - 26 January 1995 (QM S64121); 5 males, 2 females, same data, 14 December 1994 - 26 January 1995 (QM S57039); 1 female, 1 juv., same data, 26 January - 20 April 1995 (QM S64127); 1 male, Boggomoss \#30, Farnham Stud, Price Creek, 2527'29"S, 15003'00"E, 11 September 1996, PL, HJ, DP, BS66 (QM S36492); 1 male, Deer Reserve, via Kilcoy, 26 $6^{\circ} 57^{\prime} \mathrm{S}, 152^{\circ} 34^{\prime} \mathrm{E}, 11$ January - 29 March 1975, pitfall trap, G. and S. Monteith (QM W5819); 2 males, 1 female, Elginvale, $27^{\circ} 58^{\prime} \mathrm{S}, 152^{\circ} 22^{\prime} \mathrm{E}, 17$ October - 12 December 1976, pitfall trap, G. Monteith, GM77B/1, 610m (QM S61959-60); 1 male, Mt Asplenium, 28 $09^{\circ} \mathrm{S}, 152^{\circ} 26^{\prime} \mathrm{E}, 20$ December 1992 - 1 March 1993, pitfall trap, G. Monteith (QM

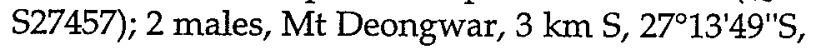
$152^{\circ} 15^{\prime} 25^{\prime \prime E}, 14$ October - 31 December 1998, pitfall trap, G. Monteith, D. Cook, site 2, rainforest (QM S57948); 4 males, 5 females, 4 juv., same data, 14 October - 30 December 1998, site 3 (QM S52578); 1 female, 2 juv., same data, 30 December 1998 - 26 March 1999 (QM S34948); 1 female, Tungi Creek, via Jimna, $26^{\circ} 40^{\prime} \mathrm{S}, 152^{\circ} 28^{\prime} \mathrm{E}, 20$ January - 9 March 1997, pitfall trap, G. Monteith, rainforest (QM S38090); 10 males, same data, 18 December 1996 20 January 1997 (QM S41657). South Australia: 13 males, 2 females, Cleland National Park, Wine Shanty Track, $34^{\circ} 57^{\prime} \mathrm{S}, 138^{\circ} 42^{\prime} \mathrm{E}, 28$ November -5 December 1994, pitfall trap, E. G. Matthews, J. A. Forrest (SAM NN13309-23); 3 males, 1 female, Eurilla Conservation Park, $0.7 \mathrm{~km}$ SE Mt Lofty, $34^{\circ} 58^{\prime} 47^{\prime \prime} \mathrm{S}, 138^{\circ} 42^{\prime} 45^{\prime \prime} \mathrm{E}, 26$ November - 1 December 2000, pitfall trap, Sthn Mt Lofty Ranges Survey, ADE021 (SAM NN13332-5); 1 female, Fleurieu Peninsula .(no exact location), February - March 2000, pitfall trap, Sthn Mt Lofty Ranges Survey (SAM NN13331); 1 male, Loftia Park, heathfield off Evans Drive, $35^{\circ} 02^{\prime} \mathrm{S}, 138^{\circ} 42^{\prime} \mathrm{E}, 28$ November - 5 December 1994, pitfall trap, E. G. Matthews, J. A. Forrest (SAM NN13308); 1 male, Scott Creek Conservation Park, MacKreath Creek, $35^{\circ} 06^{\prime}$ S, $138^{\circ} 42^{\prime} \mathrm{E}, 1993$, pitfall trap, T. Herbert (SAM NN13307); 3 males, Parawa, $2 \mathrm{~km}$ WSW, $35^{\circ} 33^{\prime} 01^{\prime \prime} \mathrm{S}$, $138^{\circ} 22^{\prime} 08^{\prime \prime} \mathrm{E}, 6$ - 10 March 1997, pitfall trap, SEG Fleurieu Survey, TOR001 (SAM NN13327-9); 1 male, Parawa, 5km ENE, 35 32' $27^{\prime \prime} \mathrm{S}, 138^{\circ} 24^{\prime} 24^{\prime \prime} \mathrm{E}, 4$ - 10 December 1996, pitfall trap, Fleurieu Swamps Survey, TOR00801 (SAM NN13337); 1 male, Penneshaw P.O, $8 \mathrm{~km}$ SE, Kangaroo Island,

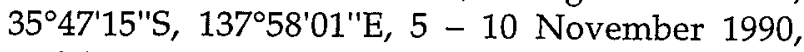
pitfall trap, KI Survey (\#77) (SAM NN13336); 1 female, Rocky River Headquarter, Flinders Chase National Park, Kangaroo Island, 35 $57^{\prime} 00^{\prime \prime} \mathrm{S}$, $136^{\circ} 42^{\prime} 30^{\prime \prime}$, 1 December 1982, B. Guerin et al., in ground litter (SAM NN13286); 5 males, 2 females, same location, $7-8$ November 1987, pitfall trap, D. Hirst (SAM NN13287-93); 1 female, Spring Mount,
$1.5 \mathrm{~km}$ WSW, Mt Lofty Ranges, $35^{\circ} 26^{\prime} 53^{\prime \prime} \mathrm{S}$, 138 31'36"E, 20 - 25 February 2000, Sthn Mt Lofty Ranges Survey, WIL02601 (SAM NN13330); 4 males, 4 females, 6 juv., Waterfall Creek, Western River Conservation Park, Kangaroo Island, $35^{\circ} 42^{\prime} \mathrm{S}$, $136^{\circ} 54^{\prime}$ E, 3 - 4 November 1987, pitfall trap, D. Hirst (SAM NN13299-306); 3 males, 2 females, 1 juv., same location, 3 November 1987, D. Hirst, in leaf litter (SAM NN13294-8). Tasmania: 1 female, no exact location, no date, PF38 11/74 M9 (QVMAG 13:44908); 1 female, 1 juv., Algonkian Mountain, $42^{\circ} 23^{\prime} \mathrm{S}, 146^{\circ} 03^{\prime} \mathrm{E}, 26$ February 1991, S. J. Smith (PW and H), GRNIVE229.069, S. Smith no. 5003, in litter under King Billy pine forest, N.W. slope, $970 \mathrm{~m}$, 11.15pm (TMAG J2251); 1 female, Ben Lomond, $41^{\circ} 34^{\prime} S, 147^{\circ} 41^{\prime} \mathrm{E}, 1$ January 1971 , R. Upson, 1000'2000' (QVMAG 13:44336); 2 females, Cataract Gorge, Launceston, $41^{\circ} 27^{\prime} \mathrm{S}, 147^{\circ} 08^{\prime} \mathrm{E}, 7$ February 1987, R. Raven, J. Gallon, T. Churchill, open forest (QM S11554); 1 male, Cataract Gorge, Launceston, $41^{\circ} 26^{\prime} \mathrm{S}, 147^{\circ} 08^{\prime} \mathrm{E}, 12$ October 2001, pitfall trap, S. Leighton, Migas plomleyi Survey, site 1 (QVMAG 13:44341); 4 males, 1 female, same data, 3 December 2001, site 2 (QVMAG 13:44345.); 1 female, Central Plateau, Butlers Road near Tarraleah, $42^{\circ} 18^{\prime} \mathrm{S}$, 146을 $\mathrm{E}, 20$ October 1992 (QVMAG 13:44327); 1 female, Central Plateau, D'Arcys Bluff near Tarraleah, $42^{\circ} 18^{\prime} \mathrm{S}, 146^{\circ} 26^{\prime} \mathrm{E}$, 16 November 1992 , pitfall trap, R. Brereton, mixed wet forest, shrubby understorey, 880m (QVMAG 13:44329); 1 female, Greens Beach, $41^{\circ} 05^{\prime} \mathrm{S}, 146^{\circ} 44^{\prime} \mathrm{E}, 18$ January $1971, \mathrm{R}$. H. Green (QVMAG 13:43004); 1 female, Kallista, $42^{\circ} 46^{\prime}$ S, $146^{\circ} 34^{\prime}$ E, 19 April 1938, L.R. (TMAG J3512); 1 female, Lake St Clair, $42^{\circ} 07^{\prime} \mathrm{S}, 146^{\circ} 10^{\prime} \mathrm{E}, 7$ April 1973, R. Upson (QVMAG 13:43253); 1 male, 4 females, 1 juv., Lake St Clair, Pump House Point, $42^{\circ} 06^{\prime} S, 146^{\circ} 12^{\prime} \mathrm{E}, 11$ March 1995, T. Kingston et al., PF 23, 25, 50, 740m (QVMAG 13:23846-7, 13:23877); 28 males, 4 females, same data, 27 December 1994, PF 14, 19, 21-22, 24, 27-28, 38, 54, 57 DP343 378, 740m (QVMAG 13:17934, 13:17948, 13:17962, 13:23668, 13:23689, 13:23714; 13:23748, 13:23752, 13:23757, 13:23770); 1 male, same data, 7 December 1994, 200-1, 740m (QVMAG 13:16819); 1 male, same data, 700-1 (QVMAG 13:23516); 20 males, 8 females, 4 juv., same data, 8 December 1994, PF 11-12, 14, 17, 19-25, 740m (QVMAG 13:16747, 13:16794, 13:16799, 13:23526, 13:23560, 13:23563, 13:23568, 13:23580, 13:23583, 13:23595, 13:23602, 13:23644); 1 male, same data, 200-3 (QVMAG 13:16276); 8 males, same data, PF 05, 27-28, 48 (QVMAG 13:44334, 13:16781, 13:16793, 13:16796); 1 female, Launceston, $41^{\circ} 26^{\prime} \mathrm{S}, 147^{\circ} 08^{\prime} \mathrm{E}, 16$ November 1970 (QVMAG 13:42999); 1 female, same location, 3 April 1971, R. T. Green (QVMAG 13:44331); 1 female, same location, 9 November 1970, R. Upson (QVMAG 13:44337); 1 male, same data (QVMAG 13:43247); 1 female, Launceston, 43 High St, $41^{\circ} 26^{\prime} S, 147^{\circ} 08^{\prime} \mathrm{E}$, 30 January 1971, R. T. Green (QVMAG 13:44330); 3 
males, Lilydale, Merthyr Park, $41^{\circ} 14^{\prime} S, 147^{\circ} 11^{\prime} \mathrm{E}, 3$ November 1998, pitfall trap, T. J. Kingston et al., PF 16 (QVMAG 13:44923); 1 female, Little Donaldson River, 4123'01'S, 145¹3'13'E, 24 January 1987, N. Weston, ANZSES, riparian rainforest, litter, $330 \mathrm{~m}$ (QM S51044); 1 male, Maggs Mountain, 41 $45^{\prime} \mathrm{S}$, $146^{\circ} 11 ' \mathrm{E}, 8$ October 1979, R. H. Green, compt. 2 turn off (QVMAG 13:44335); 2 males, same location, 11 February 1997, pitfall trap, R. H. Green, Forestry Tasmania donation, site A (QVMAG 13:44343); 1 male, same location, 25 November 1986, pitfall trap, R. H. Green, site A (QVMAG 13:44333); 1 female, same location, 17 February 1981, pitfall trap, R. H. Green, Forestry Tasmania donation, site $C$ (QVMAG 13:44344); 1 female, same location, 26 November 1987, R. H. Green, site E (QVMAG 13:42753); 2 females, same location, 20 February 1989, pitfall trap, R. H. Green, site F (QVMAG 13:44332); 1 male, Maggs Mountain Road, $41^{\circ} 45^{\prime} \mathrm{S}$, $146^{\circ} 11^{\prime} \mathrm{E}, 3$ March 1979, R. H. Green, wet sclerophyll (QVMAG 13:44326); 1 male, 1 female, Maggs Mountain, $5 \mathrm{~km}$ up road from Field Station, $41^{\circ} 45^{\prime} \mathrm{S}$, $146^{\circ} 09^{\prime} \mathrm{E}, 4$ February 1980, R. H. Green (QVMAG 13:44328); 1 male, Maggs Mountain, $W$ of Field Station, $41^{\circ} 45^{\prime} \mathrm{S}, 146^{\circ} 09^{\prime} \mathrm{E}, 4$ February 1980 , R. H. Green (QVMAG 13:42754); 2 males, 1 female, same location, 6 November 1979, R. H. Green (QVMAG 13:42575); 9 males, 2 females, Maggs Mountain, $500 \mathrm{~m} \mathrm{~W}$ of hut, $41^{\circ} 45^{\prime} \mathrm{S}, 146^{\circ} 09^{\prime} \mathrm{E}, 3$ March 1979 , R. H. Green, dry sclerophyll (QVMAG 13:42752); 2

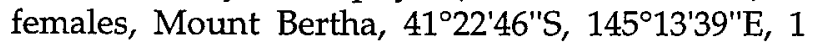
January 1997, N. Weston, ANZSES, temperate rainforest, 350m (QM S50813); 14 males, 2 females, Peters Link Road, $20 \mathrm{~km}$ E of site A, $41^{\circ} 09^{\prime} S$, $148^{\circ} 08^{\prime} \mathrm{E}, 1$ November 1993, P. Cranston, J. Trueman, site B (QM S18985); 1 male, Port Sorell, Squeaking Point, $41^{\circ} 11^{\prime} \mathrm{S}, 146^{\circ} 34^{\prime} \mathrm{E}, 29$ March 1995 , T. Kingston et al., DQ632 398, 10m (QVMAG 13:42784); 1 male, 2 females, Rosebery, Snake Gully, $41^{\circ} 47^{\prime} \mathrm{S}, 145^{\circ} 33^{\prime} \mathrm{E}, 2$ December 1997, L. J. Boutin, mixed forest, under rock (QVMAG 13:24073); 1 male, St Mary's, off German Town Road, 41 $34^{\prime}$ 'S, $148^{\circ} 11^{\prime} \mathrm{E}, 8$ December 1999, L. J. Boutin, under rock (QVMAG 13:44346); 1 female, 1 juv., Strathgordon Caravan Park, campsite, $42^{\circ} 40^{\prime} \mathrm{S}, 146^{\circ} 02^{\prime} \mathrm{E}, 24$ January 1987, R.Raven, J. Gallon (QM S5748); 1 female, Warra, 430.'S, $146^{\circ} 43^{\prime} \mathrm{E}$, December 1997, D. Bashford, Forestry Tasmania donation, on ground (QVMAG 13:44340); 1 male, Warra, 4304'S, $146^{\circ} 43^{\prime} \mathrm{E}$, December 1997, pitfall trap, D. Bashford, Forestry Tasmania donation, on ground at areas (QVMAG 13:44342); 1 male, Warra Forest, near Geeveston, $43^{\circ} 10^{\prime}$ S, $146^{\circ} 54^{\prime} \mathrm{E}$, 29 November 2001, beating, L. J. Boutin, control site \#C, under bark, by hand at night (QVMAG 13:44339); 2 males, same location and date, 29 November 2001, by hand, on ground, 10am (QVMAG 13:44338); 1 male, Yorktown, Yorktown Road, 41 ${ }^{\circ} 09^{\prime} \mathrm{S}, 146^{\circ} 46^{\prime} \mathrm{E}, 24$ April 1972, R. Upson (QVMAG 13:42311); Victoria:
2 males, 2 females, 2 juv., Cheniston, Macedon, $37^{\circ} 25^{\prime} \mathrm{S}, 144^{\circ} 34^{\prime} \mathrm{E}$, no date, H. R. Hogg collection, listed as "Lycosa berenice (?)" by Hogg (1900) (BMNH 1924.3.1.1008-13); 1 female, Forrest, $3 \mathrm{~km} \mathrm{~N}$ of, $28^{\circ} 30^{\prime} \mathrm{S}, 143^{\circ} 43^{\prime} \mathrm{E}, 8 \mathrm{March} 1986, \mathrm{M}$. S. Harvey, B. J. Scott (WAM T553139); 1 male, 3 juv., Omeo Hwy, $52 \mathrm{~km} \mathrm{~N}$ of Omeo, $37^{\circ} 46^{\prime} \mathrm{S}, 147^{\circ} 42^{\prime} \mathrm{E}, 13$ April 1978 M. R. Gray, logs, 1094m (AM KS45362); 1 female, Starling Gap, $37^{\circ} 48^{\prime} 52^{\prime \prime S}, 145^{\circ} 48^{\prime} 04^{\prime \prime E}, 2$ January 2004, V.W. Framenau, M.L. and J. Thomas (WAM T56088); 15 males, Upper Yarra Region, $11.0 \mathrm{~km} \mathrm{NE}$ McMahons Creek, 37³9'S, 145 $56^{\prime} \mathrm{E}, 14-24$ November 1988, L. Lumsden, DCE Upper Yarra Survey, site 6 (MV K7739); 1 male, Upper Yarra Region, $11.3 \mathrm{~km}$ ENE McMahons Creek, 37 $40^{\prime} \mathrm{S}$, $145^{\circ} 57^{\prime} \mathrm{E}, 14$ - 24 November 1988, L. Lumsden, DCE Upper Yarra Survey, site 7 (MV K7737); 47 males, 4 females, Upper Yarra Region, $11.4 \mathrm{~km}$ ENE McMahons Creek, $37^{\circ} 41^{\prime} \mathrm{S}, 145^{\circ} 57^{\prime} \mathrm{E}, 14-24$ November 1988, L. Lumsden, DCE Upper Yarra Survey, site 8 (MV K7738); 5 males, 1 female, Upper Yarra Region, $9.2 \mathrm{~km}$ NW Toorongo, $37^{\circ} 44^{\prime} \mathrm{S}$, $146^{\circ} 02^{\prime} \mathrm{E}, 14-24$ November 1988, L. Lumsden, DCE Upper Yarra Survey, site 1 (MV K7736).

\section{Diagnosis}

Artoria albopilata is very similar to $A$. gloriosa from Lord Howe Island. Males differ in the shape of the median apophysis, which ends in three lobes in $A$. albopilata but only two tips in $A$. gloriosa. In addition, the tip of the embolus is sharp and sickle-shaped in $A$. albopilata, but broad and blunt in $A$. gloriosa. Females differ in the shape of the epigyne, in particular the anterior border, which is semicircular in $A$. albopilata, but undulating in $A$. gloriosa. In addition, the median septum fills the atrium in $A$. albopilata, but is truncated anteriorly in $A$. gloriosa.

\section{Description}

Male (based on QVMAG 13:44346). Carapace: Dark brown, head and posterior flanks distinctly darker; distinct light brown median band, anteriorly as wide as PLE but gradually narrowing towards posterior margin; wide light brown submarginal bands; indistinct dark grey radial pattern; carapace covered with black setae, dense white setae in head region and on median band, less dense white setae in submarginal band; black bristles between and lateral of eyes, one long brown bristle between AME, two long brown bristles below AE. Sternum: Dark brown; black bristles increasing in length towards margins; few shorter white setae. Labium: Dark brown; front end truncate and white. Chelicerae: Dark brown, basally lighter; sparsely covered with black setae and white setae in basal half; three retromarginal teeth, with the basal shortest; three promarginal teeth, with the middle largest. Pedipalp (Figures 1A-C): Cymbium tip with approx. twelve macrosetae and some scopulous 


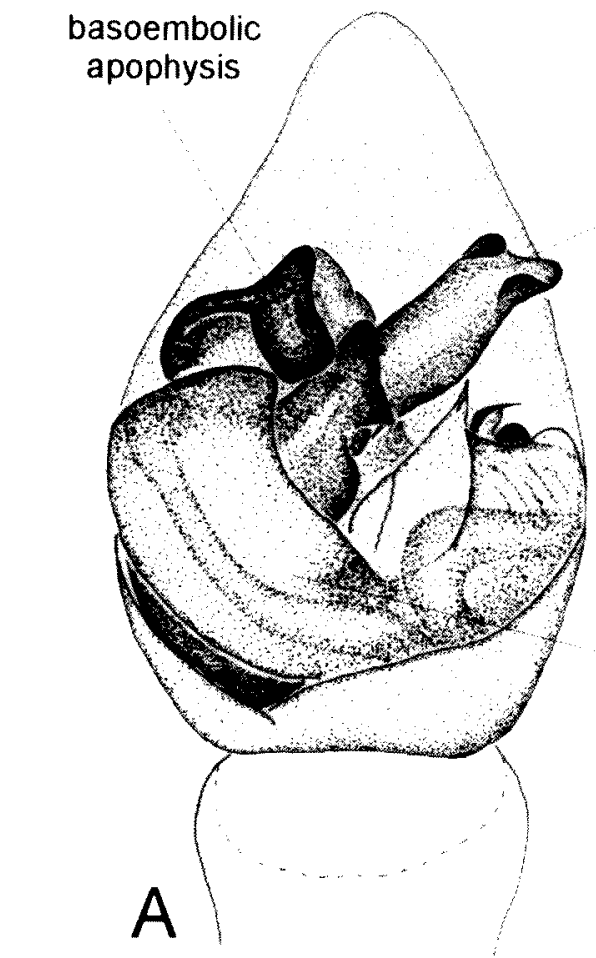

basoembolic apophysis

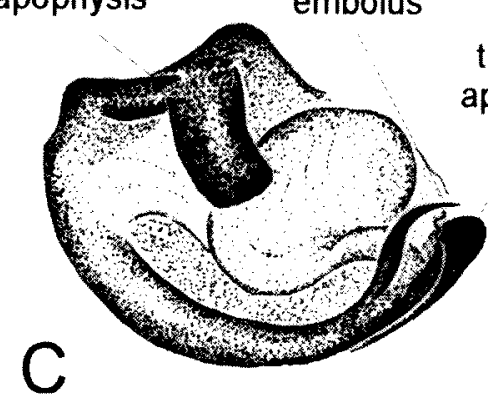

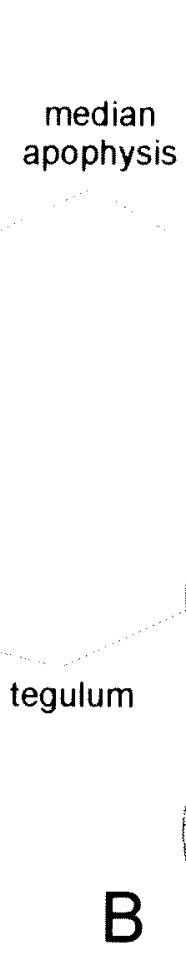

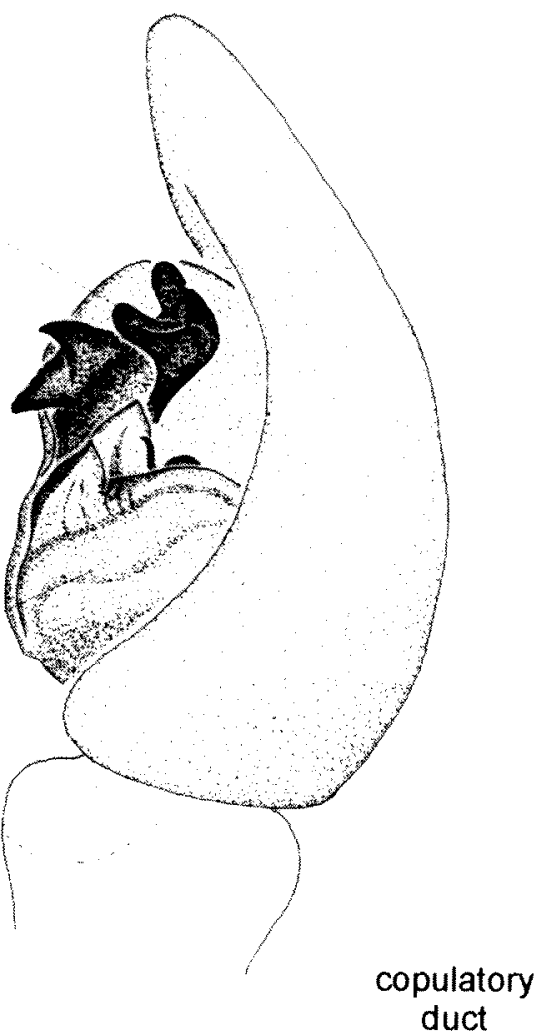

atrium

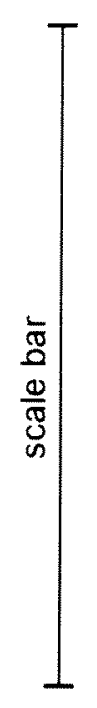

spermatheca

terminal apophysis

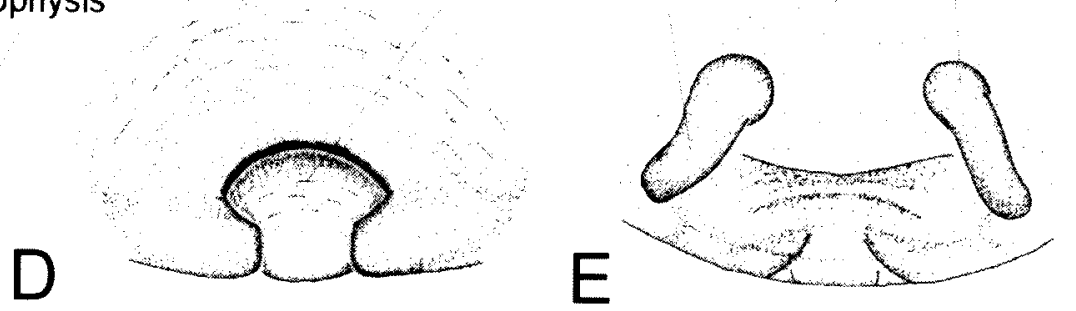

Figure 1 Artoria albopilata (Urquhart, 1893), male (QVMAG 13:44346 from St Marys, off German Town Road, Tasmania): A - left pedipalp, ventral view; B - left pedipalp, retrolateral view; $\mathrm{C}$ - left pedipalp, apical part of bulbus. Female (QVMAG 13:44336 from Ben Lomond, Tasmania): D - epigyne, ventral view; E - epigyne, dorsal view. Scale bar: A, B $-0.86 \mathrm{~mm} ; C-0.99 \mathrm{~mm}$; D, E-1.03 mm.

setae dorsally; median apophysis ending in three lobes, of which the lateral ones are folded ventrally, median apophysis with a longitudinal ridge in basal half that has two shark tooth-like tips; embolus ending in a sharp, sickle-shaped tip (Figure 1C). Abdomen: Dark olive grey and covered with whitish and longer black setae; light heart mark in anterior half very distinct through a dense layer of white setae; heart mark constricted and narrow in posterior half; black patches laterally at base of heart mark, at its constriction and its posterior end; yellow patches lateral of heart mark near its base behind black patches; venter brown, lateral borders a light brown dotted line, two indistinct longitudinal yellow stripes in anterior half; covered with whitish and brown setae; spinnerets yellow with brown pigmentation. Legs: Leg formula IV > I $>$ II > III; dark brown, with indistinct darker annulations; spination of leg I: Femur: 3 dorsal, 1 (small) retrolateral, 1 apicoprolateral, 1 apicoretrolateral; patella: 1 dorsal in basal half; tibia: 3 ventral pairs, 2 prolateral, 2 retrolateral; metatarsus: 3 ventral pairs, 2 prolateral, 1 retrolateral, 1 apicoventral, 1 apicoprolateral, 1 apicoretrolateral.

Female (based on QVMAG 13:44336). Carapace: As male, generally lighter. Sternum, labium and chelicerae: as male. Epigyne (Figures 1D, E): Ventral view: simple atrium with semicircular anterior border and yellow median septum that fills out the whole atrium (Figure 1D); dorsal view: indistinct spermathecae at the end of thick copulatory ducts that are directed anteriomedially (Figure 1E). Abdomen: As male, but generally lighter and therefore black patches more distinct; four additional black patches in posterior half; venter as 
male but lighter (light brown); all spinnerets yellow. Legs: Leg formula IV > I > II > III; light brown, very distinct dark annulations; spination of leg I: Femur: 3 dorsal, 1 (small) retrolateral, 1 apicoprolateral, 1 apicoretrolateral; patella: 1 dorsal in basal half; tibia: 3 ventral pairs, 1 prolateral; metatarsus: 3 ventral pairs, 2 prolateral, 1 retrolateral, 1 apicoprolateral, 1 apicoretrolateral, 1 apicoventral.

Measurements. Male QVMAG 13:44346 (female QVMAG 13:44336): TL 4.65 (5.55), CL 2.7 (3.0), CW 1.95 (2.1). Eyes: AME 0.07 (0.07), ALE $0.07(0.09)$, PME $0.23(0.26)$, PLE $0.17(0.20)$. Row of eyes: AE 0.52 (0.57), PME 0.67 (0.76), PLE $0.84(1.02)$. Sternum (length/width) $1.58 / 1.05$ (1.28/1.05). Labium (length/width) 0.32/0.32 (0.46/0.46). AL 1.95 (2.85), AW 1.35 (2.1). Legs: Lengths of segments (femur + patella $/$ tibia + metatarsus + tarsus $=$ total length): Pedipalp 0.92+0.80+- +0.94 $=2.66$, I $1.80+2.26+1.54+0.94=6.54$, II $1.75+2.17+1.52+0.82=$ 6.27 , III $1.75+1.97+1.69+0.82=6.23$, IV $2.26+2.77+2.57+1.12=8.72$ (Pedipalp $1.00+1.00+-$ $+0.80=2.80$, I $1.77+2.20+1.37+0.92=6.26$, II $1.72+2.00+1.40+0.89=6.21$, III $1.72+2.03+1.60+0.83$ $=6.18$, IV $2.17+2.80+2.52+1.14=8.63)$.

Variation. Males (females) (range, mean \pm s.d.): TL $4.05-6.00,4.77 \pm 0.53 ; \mathrm{n}=21 ; \mathrm{CL} 2.25-2.85,2.54 \pm$ $0.17 ; \mathrm{n}=21 ; \mathrm{CW} 1.65-2.1,1.86 \pm 0.13 ; \mathrm{n}=21$ (TL $4.35-7.65,6.11 \pm 0.83, \mathrm{n}=18$; CL $2.55-3.60,3.07 \pm$ $0.24, \mathrm{n}=20 ; \mathrm{CW} 1.88-2.55,2.24 \pm 0.19 ; \mathrm{n}=20$ ).

\section{Remarks}

The type material of $A$. albopilata, as others of Urquhart's types, must be considered lost (Forster 1967, Court and Forster 1988, Cor Vink personal communication), however, Urquhart (1893) provided a very accurate description of both the male and the female of this species. The combination of characters described clearly identify this species as an Artoria. I have examined both Tasmanian museum collections (TMAG, QVMAG) in which ca. 20 species of Artoria are represented. Urquhart's (1893) description of male and female, including a detailed account of the genitalia, clearly identifies the species illustrated here. Artoria albopilata conforms to the generic definition of Artoria given in Framenau (2002), in particular due to the presence of a strong basoembolic apophysis on the male pedipalp and is consequently transferred from $L y \cos a$.

L. Koch (1877) described Trochosa expolita (L. Koch, 1877) from three females on loan from the MHNT, and a male on loan from Eugène Simon. Recent investigations of the material deposited in the MHNT provided a vial with a single female of A. albopilata (MHNT AR0825), clearly labeled 'Lycosa expolita' from Brisbane. This female, presumably a syntype of $T$. expolita, was therefore misidentified. The revision of a new Australian lycosid genus that includes $T$. expolita (and the

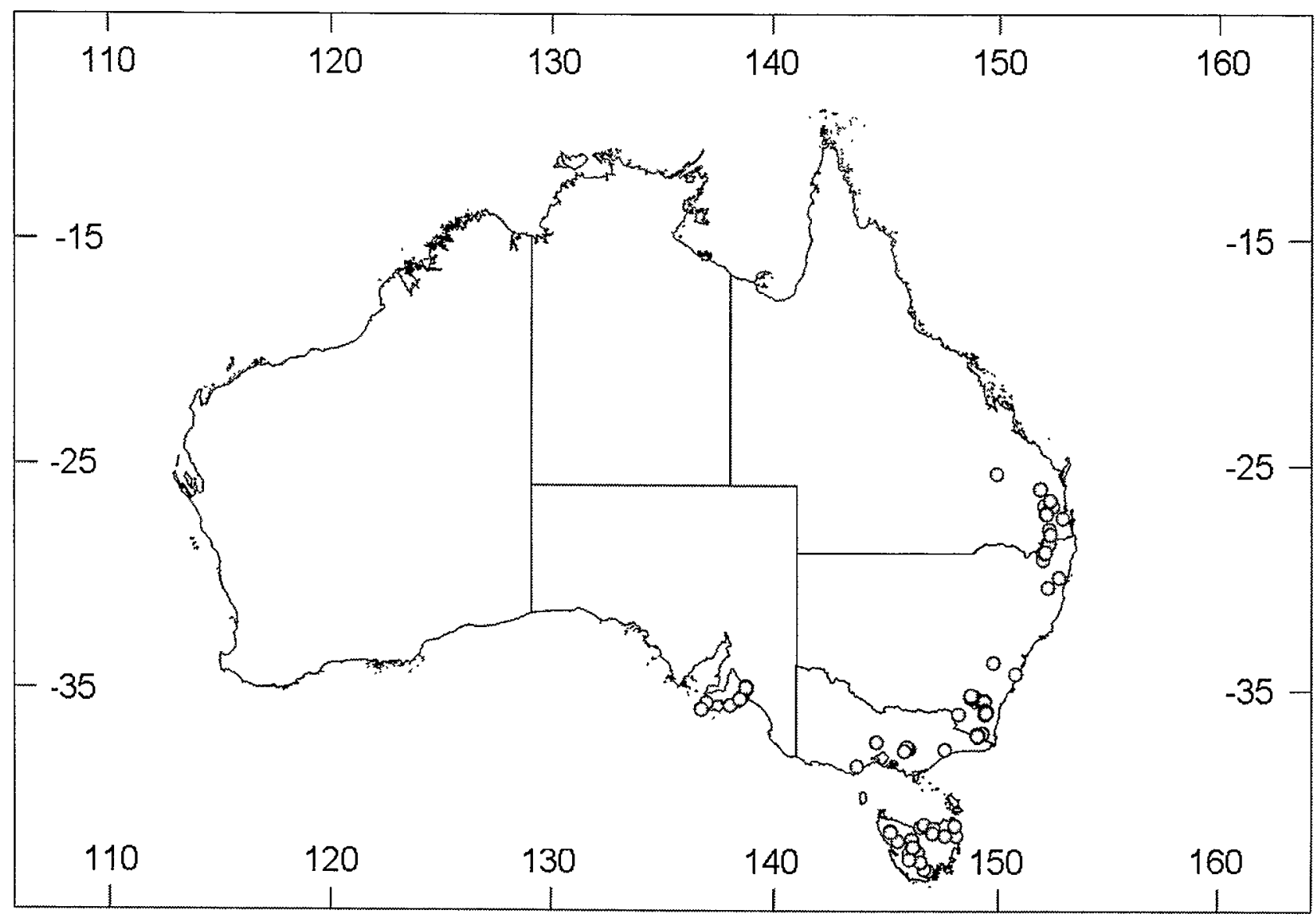

Figure 2 Records of Artoria albopilata (Urquhart, 1893). 
designation of a lectotype series for this species) is subject of a forthcoming paper as part of the current revision of the wolf spiders of Australia.

\section{Distribution}

South-eastern mainland Australia (NSW, Qld, Vic, SA) and Tasmania (Figure 2).

Artoria berenice (L. Koch, 1877), comb. nov. Figures 3, 4

Lycosa berenice L. Koch, 1877: 937-938, plate 81, figures 3, 3A.- Rainbow, 1911: 265; McKay, 1985: 75.

Pardosa versicolor L. Koch, 1877: 966-968, plate 84, figure 4.- Rainbow, 1911: 276; Roewer, 1955: 185; McKay, 1973: 378; McKay, 1985: 85. New synonymy.

Lycosa naevia L. Koch, 1878: 978-79, plate 85, Figures 5, 5A (preoccupied by Lycosa naevia L. Koch, 1875; = Pardosa naevia (L. Koch, 1875)).Rainbow, 1911: 270. New synonymy.

Lycosa berenice (?) L. Koch.- Hogg, 1900: 77. (Question mark in brackets in original citation.)

Lycosa ambrymiana Berland, 1938: 184-185, figures 153-156.- Roewer, 1955: 271. New synonymy.

Lycosa ambrymiana Berland, 1932.- Bonnet, 1957: 2633 (date misquoted).

Tarentula naeviella Roewer, 1951: 442 (replacement name for Lycosa naevia).

Avicosa berenice (L. Koch).-- Roewer, 1955: 236.

Hogna naeviella (Roewer).- Roewer, 1955: 253; Rack, 1961: 38.

Lycosa naeviella (Roewer).- McKay, 1973: 379; McKay, 1985: 80.

Schizocosa berenice (L. Koch).- McKay, 1973: 381.

Artoria versicolor (L. Koch).- Framenau, 2002: 230231, figures 27A-F, 28.

\section{Types}

Holotype female of Lycosa berenice L. Koch, 1877: no locality given, Bradley Collection, considered lost. Not examined.

Syntypes of Pardosa versicolor, unknown number of male and female specimens, Sydney, New South Wales, 33 $53^{\prime} \mathrm{S}, 1^{\circ} 11^{\circ} 13^{\prime} \mathrm{E}$, Bradley Collection, considered lost (contra Framenau, 2002). Not examined.

Holotype female of Lycosa naevia L. Koch, 1878: Sydney, New South Wales, 335' Museum Godeffroy; No. 14560; ZMH, Rack (1961)catalogue 469. Examined.

Holotype female of Lycosa ambrymiana Berland, 1938: Mont Marum, Ambrym, Vanuatu, $16^{\circ} 15^{\prime} \mathrm{S}$, $168^{\circ} 07^{\prime} \mathrm{E}, 9$ January 1936, Aubert de la Ruë, 900m (MNHP). Not examined.

Allotype male of Lycosa ambrymiana Berland, 1938, data as holotype (MNHP). Not examined.

\section{Remarks}

Lycosa berenice L. Koch, 1877 was described from the Bradley Collection and the female holotype, similar to the holotype of $A$. pruinosa, must be considered lost. However, the original species description and illustrations of $L$. berenice strongly suggest a synonymy with $A$. versicolor which was redescribed in detail by Framenau (2002). The body colouration of both species is very similar and uncommon within Artoria. The epigyne of L. berenice varies somewhat from that of $A$. versicolor in that it is comparatively shorter and its lateral borders touch each other anteriorly. However, the examination of a large number of specimens in Australian collections revealed this to be a common variation of this species. Therefore, $A$. berenice is here transferred from Schizocosa to Artoria and considered a senior synonym of $A$. versicolor.

Likewise, the external and internal (visible through the cuticle of the specimen) genitalia of the holotype of Lycosa naeviella Roewer, 1951 (replacement name for L. naevia L. Koch, 1878) (Figure 3) conform to the genitalia of $A$. berenice, with the exception of a minute incision at its posterior rim. This variation caused L. Koch (1877) to treat $L$. naeviella as a separate species, however, this incision also represents a common variation in this species. Therefore, L. naeviella must be considered a junior synonym of $A$. berenice.

An assessment of the original description of Lycosa ambrymiana Berland, 1938 from Vanuatu suggested very close affinities of this species with $A$. berenice. Therefore, the holotype female and

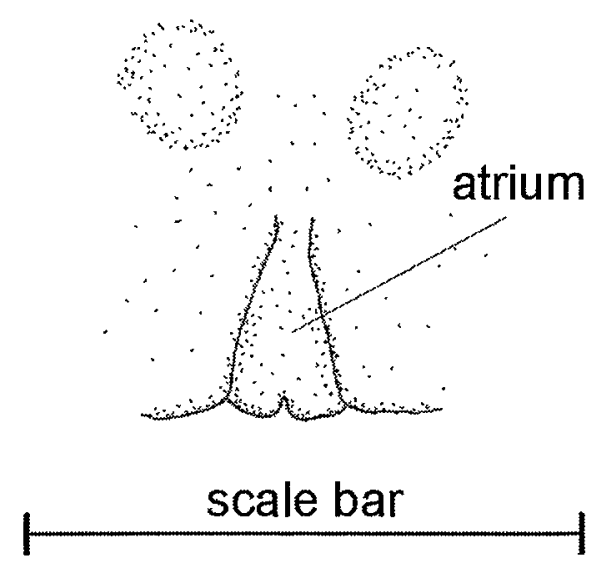

Figure 3 Artoria berenice (L. Koch, 1877), holotype female of Lycosa naevia L. Koch, 1877 (ZMH, Rack (1961)-catalogue 469, from Sydney, New South Wales), epigyne, ventral view. Scale bar: $0.72 \mathrm{~mm}$. 


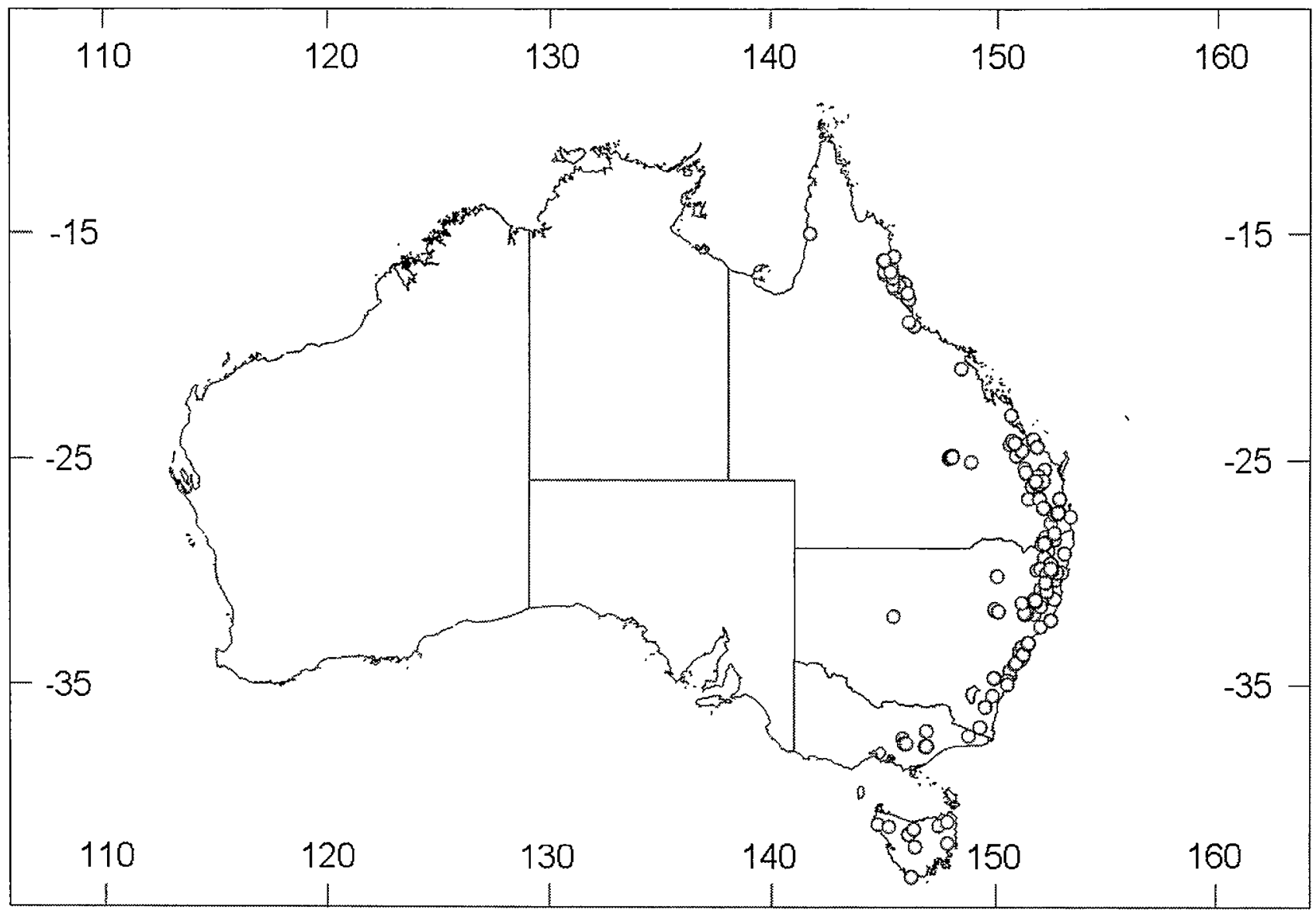

Figure 4 Records of Artoria berenice (L. Koch, 1877) in Australia. The species is also known from New Caledonia and Vanuatu.

allotype male were requested from the MNHP, however, the material received contained only nontype material ( 3 females, 1 male and 9 juveniles) from the type series of this species (Berland 1938). Despite the unavailability of the types, there is no doubt that these specimens represent the same species as the types. There are no genitalic or somatic differences between these spiders and $A$. berenice from Australia. Therefore L. ambrymiana must be considered a junior synonym of $A$. berenice.

As with $A$. berenice, $A$. versicolor was originally described from material from the Bradley Collection. Framenau (2002) listed syntypes lodged at the MUUS, where parts of the Bradley Collection were believed to be housed. However, a more detailed investigation of the MMUS revealed that the specimens present there do not belong to the Bradley Collection. In particular, none of the specimen vials included any of the typical framed species labels in L. Koch's handwriting. Therefore, Framenau's (2002) designation of the type material must be regarded as erroneous and the syntypes of A. versicolor considered lost.

\section{Distribution}

Common in forest litter in south-eastern mainland Australia (NSW, Qld, Vic), and Tasmania (Figure 4); also in New Caledonia and Vanuatu.

\section{Artoria cingulipes Simon, 1909 \\ Figures 5A-E, 6}

Artoria cingulipes Simon, 1909: 193, figure 10.Rainbow, 1911: 275; Bonnet, 1955: 750; McKay, 1973: 380; McKay, 1985: 74; Moritz, 1992: 312; Framenau, 2002: 214-215, figures 5A-B, 6.

Artoriella cingulipes (Simon).- Roewer, 1955: 233; Roewer, 1960: 563.

\section{Type}

Holotype female of Artoria cingulipes Simon, 1909: Collie, Western Australia, $33^{\circ} 21^{\prime} \mathrm{S}, 116^{\circ} 09^{\prime} \mathrm{E}, \mathrm{W}$. Michaelsen, R. Hartmeyer ('Hamburger südwestaustralische Expedition'), Station 137 (Michaelsen and Hartmeyer (1907), from German: '26 August 1905, mountain forest, alt. 185m, Darling Ranges'), ZMB 10547. Examined.

\section{Other material examined}

South Australia: 1 female, Arltunga Homestead, $1.4 \mathrm{~km}$ SSW, $36^{\circ} 20^{\prime} 34^{\prime \prime} \mathrm{S}, 140^{\circ} 57^{\prime} 28^{\prime \prime} \mathrm{E}, 11$ - 13 December 1995, pitfall trap, Box Bulloak Survey, BBG01801 (SAM NN13228); 1 female, Bald Hill, NW of Tod River Reservoir, Koppio Hills, 34²9'30"S, 13546'00"E, 26 March 1987, D. C. Lee, D. Hirst, near creek (SAM NN13225); 1 male, Cape Borda Cemetery, $4.3 \mathrm{~km}$ SE, Flinders Chase National 
Park, Kangaroo Island, 35 46 $57^{\prime \prime} \mathrm{S}, 136^{\circ} 37^{\prime 2} 21^{\prime \prime} \mathrm{E}, 22-$ 26 October 1990, pitfall trap, KI Survey (\#86) (SAM NN13179); 1 male, Cape Gantheaume, $1 \mathrm{~km} \mathrm{~N}$ Tinline, Kangaroo Island, $35^{\circ} 59^{\prime} \mathrm{S}, 137^{\circ} 37^{\prime} \mathrm{E}, 10-11$ November 1987, pitfall trap, D. Hirst (SAM NN13186); 2 males, Dudley Conservation Park, $13.6 \mathrm{~km}$ SW Penneshaw P.O., Kangaroo Island, 3549'22"S, 13751'32"E, 4 - 9 November 1990, pitfall trap, KI Survey DU00701 (SAM NN13177-8); 5 females, Dudley Conservation Park, Kangaroo

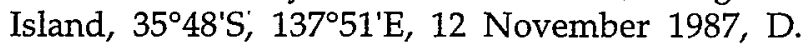
Hirst (SAM NN13191-5); 1 female, Grassdale, Kelly Hill Conservation Park, Kangaroo Island, $35^{\circ} 59^{\prime} \mathrm{S}$, $136^{\circ} 52^{\prime}$ E, 9 November 1987, D. Hirst (SAM NN13185); 1 female, Mount Rescue Conservation Park, NE Jimmys Well, $35^{\circ} 51^{\prime}$ S, $140^{\circ} 18^{\prime}$ E, 20 March 1992, vibration, D. Hirst (SAM NN13197); 5 males,

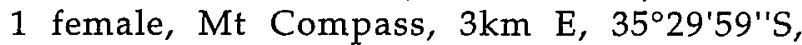
$138^{\circ} 29^{\prime} 16^{\prime \prime} \mathrm{E}, 28-31$ August 1998, pitfall trap, S.E.G Fleurieu Survey, TOR01101 (SAM NN13219-24); 1 male, Mt Rough, $12.2 \mathrm{~km}$ NNE, Watervalley, $36^{\circ} 15^{\prime} 42^{\prime \prime} \mathrm{S}, 139^{\circ} 54^{\prime} 55^{\prime \prime} \mathrm{E}, 6-15$ October 2000, pitfall trap, Waterhouse Club, WV003, Melaleuca, pink gum (SAM NN13566); 1 male, 1 female, Mt Rough,

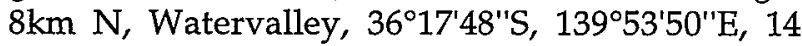
October 2000, pitfall trap, Waterhouse Club, WV001 (SAM NN13201); 1 male, 1 female, Murvio Homestead, $2.7 \mathrm{~km}$ SE, 36 $12^{\circ} 41^{\prime \prime} \mathrm{S}, 140^{\circ} 07^{\prime} 46^{\prime \prime} \mathrm{E}, 30$ September -6 October 1996, pitfall trap, NCS Gum Lagoon Survey, GLS041 (SAM NN13199-200); 2 males, 1 female, Nepean Bay, Kangaroo Island, $35^{\circ} 42^{\prime} \mathrm{S}, 137^{\circ} 37^{\prime} \mathrm{E}, 2-3$ November 1987 , pitfall trap, D. Hirst (SAM NN13187-89); 1 female, Old White Hut Well, $10.6 \mathrm{~km}$ SSE, 36 $43^{\circ} 58^{\prime \prime} \mathrm{S}, 139^{\circ} 54^{\prime} 53^{\prime \prime} \mathrm{E}, 1$ - 6 March 1987, pitfall trap, SEF Fauna Survey, DUF0902 (SAM NN13198); 2 males, Penneshaw P.O, $4.1 \mathrm{~km}$ SW, Kangaroo Island, $35^{\circ} 45^{\prime} 10^{\prime \prime} \mathrm{S}$, 137'54'20"E, November 1990, pitfall trap, KI Survey, GF00101 (\#46) (SAM NN13175-6); 1 male, Penneshaw P.O, $7.6 \mathrm{~km} \mathrm{SE}$, Kangaroo Island,

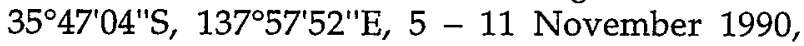
pitfall trap, KI Survey (\#76) (SAM NN13174); 4 males, 1 juv., Rocky River, $4 \mathrm{~km}$ W, Flinders Chase National Park, Kangaroo Island, 35 57 $00^{\prime \prime} \mathrm{S}$, $136^{\circ} 42^{\prime} 30^{\prime \prime} \mathrm{E}, 1$ - 7 November 1990, pitfall trap, E. G. Matthews, J. A. Forrest (SAM NN13181-4); 1 female, Seal Bay, 6.5km N, Kangaroo Island, 35 $55^{\prime} 45^{\prime \prime} \mathrm{S}$, 137'19'40"E, 1 - 7 March 1995, pitfall trap, K.I. Dunnart Survey, SD03 (SAM NN13180); 2 males, 1 female, Victor Harbour, $4.75 \mathrm{~km}$ SW, $35^{\circ} 35^{\prime} 25^{\prime \prime} \mathrm{S}$, $138^{\circ} 34^{\prime} 14^{\prime \prime}$ E, 28 - 31 August 1998, pitfall trap, S.E.G Fleurieu Survey, ENC003 (SAM NN13203-5); 11 males, 2 females, Victor Harbour, $4.75 \mathrm{~km}$ SW, $35^{\circ} 35^{\prime} 25^{\prime \prime} \mathrm{S}, 138^{\circ} 34^{\prime} 14^{\prime \prime} \mathrm{E}, 28$ - 31 August 1998, pitfall trap, S.E.G Fleurieu Survey, ENC005 (SAM NN13206-18). Western Australia: 30 males, 18 female, 5 juv., Balgarup River, Muradup,

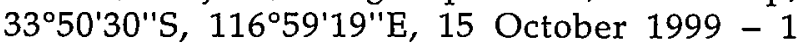
November 2000, wet pitfall traps, P. van Heurck et al., CALM Salinity Action Plan, site DA 13 (WAM T56148, T56159); 5 males, 1 female, Bella Vista Nature Reserve, $28^{\circ} 32^{\prime} 17^{\prime \prime S}, 114^{\circ} 40^{\prime} 13^{\prime \prime E}, 30$ March - 18 October 1999, wet pitfall traps, L. King, CALM Salinity Action Plan, site NO 4, traps 1-5 (WAM T56156); 7 males, 13 females, same location, 15 September 1998 - 30 March 1999, wet pitfall traps, L. King, CALM Salinity Action Plan, site NO 4 (WAM T56160); 4 males, 1 female, Binnu, SW of,

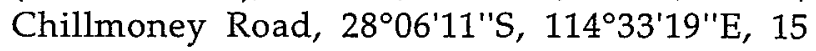
September 1998 - 31 March 1999, wet pitfall traps, L. King, CALM Salinity Action Plan, site NO 8 (WAM T56144); 1 male, 3 females, Boolading

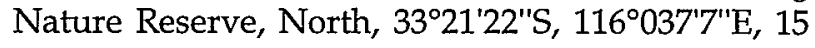
October $1999-1$ November 2000, wet pitfall traps, P. van Heurck et al., CALM Salinity Action Plan, site DA 01 (WAM T56137); 1 female, Brockman National Park, Pemberton, $34^{\circ} 30^{\prime} \mathrm{S}, 115^{\circ} 60^{\prime} \mathrm{E}, 26$ October 1969, R. W. Taylor, ANIC Berlesate No. 151, Karri forest, leaf mould (ANIC ); 16 males, 5 females, Burdett Road, near junction with Wittenoom Road, 33⒉ $7^{\prime} 30^{\prime \prime} \mathrm{S}, 1^{2} 2^{\circ} 08^{\prime} 26^{\prime \prime} \mathrm{E}, 15$ October $1999-1$ November 2000, wet pitfall traps, P. van Heurck et al., CALM Salinity Action Plan, site ES 8 (WAM T56155); 4 males, 4 females, Camel Lake Nature Reserve, East, $34^{\circ} 15^{\prime} 59^{\prime \prime}$, 117 $58^{\prime} 44^{\prime \prime} \mathrm{E}$, 15 October 1999 - 1 November 2000, wet pitfall traps, P. van Heurck et al., CALM Salinity Action Plan, site ST 7 (WAM T56141); 1 female, Camel

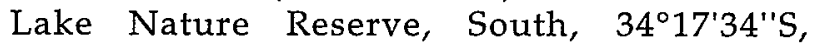
$117^{\circ} 58^{\prime} 51^{\prime \prime E}, 15$ October 1999 - 30 May and 25 November 2000, wet pitfall traps, B. Durrant, CALM Salinity Action Plan, site ST 4 (WAM T56140); 1 female, Coolinup Nature Reserve, NW

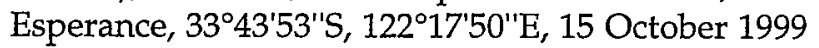
- 2 May and 29 November 2000, wet pitfall traps, P. van Heurck, CALM Salinity Action Plan, site ES 11, traps 5+5 (WAM T56145); 20 males, 4 females, Coolinup Nature Reserve, SW, Esperance, $33^{\circ} 44^{\prime} 9^{\prime \prime S}, 122^{\circ} 17^{\prime} 29^{\prime \prime} \mathrm{E}, 15$ October $1999-2$ May and 29 November 2000, wet pitfall traps, P. van Heurck, CALM Salinity Action Plan, site ES 13, traps 5+5 (WAM T56166); 5 females, Cranbrook Water Supply Reserve, $34^{\circ} 18^{\prime} 30^{\prime \prime}$, $117^{\circ} 34^{\prime} 09^{\prime \prime} \mathrm{E}, 15$ October 1999 - 31 May and 30 October 2000, wet pitfall traps, B. Durrant, CALM Salinity Action Plan, site

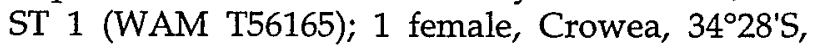
$116^{\circ} 10^{\prime}$ E, 29 October 1976, pitfall trap, S. J. Curry (WAM 79/1922); 1 male, same data, 12 November 1976 (WAM T56188); 1 male, same data, 2 December 1977 (WAM T56185); 1 male, Crowea, ridge site, $34^{\circ} 28^{\prime} \mathrm{S}, 116^{\circ} 10^{\prime} \mathrm{E}, 24$ October 1977 , pitfall trap, S. J. Curry (WAM 79/1923); 2 males, same data, 11 November 1977 (WAM T56184); 2 males, same data, 18 November 1977, open (cleared) forest (WAM T55244); 2 males, same data, 25 November 1977, open (cleared) forest (WAM 79/1914-5); 1 male, same data, 2 December 1977, open (cleared) forest (WAM T56183); 1 male, same data, 1 
November 1979, closed (uncleared) forest (WAM T56181); 1 male, 2 juv., same data, 8 November 1979, closed (uncleared) forest (WAM T56189); 1 male, same data, 31 October 1980, open forest (WAM T42124); 2 males, 1 juv., same data, 13 November 1980 (WAM 99/38-40); 2 males, same data, 21 November 1980, open (cleared) forest (WAM T56170); 4 males, same data, 28 November 1980, open forest (WAM T42127); 1 male, Crowea, creek site, $34^{\circ} 28^{\prime} \mathrm{S}, 116^{\circ} 10^{\prime} \mathrm{E}$, 22 October 1976, pitfall trap, S. J. Curry, creek site, open (cleared) forest (WAM T55243); 1 male, same data, 24 December 1976 (WAM T56187); 1 male, same data, 4 November 1977 (WAM 79/1912); 1 male, same data, 25 November 1977 (WAM T56186); 1 male, same data, 29 November 1979, open (cleared) forest with regrowth (WAM T56182); 1 male, data, 21 November 1980, open forest (WAM T42131); 6 females, 2 juv., spiderlings, Dombalup State Forest, Marri Road, 34 ${ }^{\circ} 30^{\prime} \mathrm{S}, 116^{\circ} 00^{\prime} \mathrm{E}$, 27 January - 5 March 1979, pitfall trap, M. R. Gray, FN1493, litter (AM KS15250); 5 males, 1 female, Dunn Rock, SE face, $33^{\circ} 20^{\prime} 10^{\prime \prime} \mathrm{S}, 119^{\circ} 29^{\prime} 39^{\prime \prime} \mathrm{E}, 15$ October 1999 - 2 May and 25 October 2000, wet pitfall traps, P. van Heurck, CALM Salinity Action Plan, site LK 7, traps x10 (WAM T56164); 7 males, 1 female, 'Glenbourne'

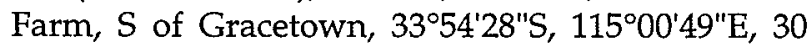
October - 1 November 1999, dry pitfall traps, L. M. Marsh et al. (WAM T55517); 2 males, same data,

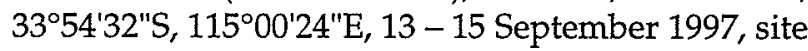
1 (WAM T55530); 1 male, same data, $24-26$ Oct 1998, site 1 (WAM T55537); 1 male, same data, 30 October - 1 November 1999, site 1 (WAM T55531); 1 male, same data, $20-23$ October 2000 , site 1 (WAM T56127); 3 males, same data, 3354'50"S, $115^{\circ} 00^{\prime} 57^{\prime \prime E}, 27$ - 28 October 1996, site 2 (WAM T56190); 1 female, 1 juv., same data, 28 - 30 June 1997, site 2 (WAM T55515); 4 males, same data, 24 26 October 1998, site 2 (WAM T55534); 5 males, same data, 30 October - 1 November 1999, site 2 (WAM T55543); 5 males, 2 females, same data, 20 23 October 2000, site 2 (WAM T56130); 1 male, same data, 26 - 28 October 2002, site 2 (WAM T58307); 2 males, same data, 25 - 27 October 2003, site 2 (WAM T58309); 4 males, 1 female, same data, 33⒌'28"S, 11500'49"E, 13 - 15 September 1997, site 3 (WAM T55540); 2 males, 2 juv., same data, $24-26$ October 1998, site 3 (WAM T55528); 15 males, 1 female, same data, 20 - 22 October 2000, site 3 (WAM T56131, T56133); 5 males, same data, 26 - 28 October 2002, site 3 (WAM T58313); 3 males, same data, 25 - 27 October 2003, site 3 (WAM T58311); 1 female, same data, 25 - 27 October 2003, site 3 (WAM T58312); 1 female, same data, 33⒌'35"S, $115^{\circ} 00^{\prime} 15^{\prime \prime} \mathrm{E}, 29$ December 1996, site 4 (WAM T55545); 1 female, 2 juv., same data, 28 - 30 June 1997, site 4 (WAM T55519); 4 males, 1 female, 1 juv., same data, 13 - 15 September 1997, site 4 (WAM T55527); 1 female, same data, $24-26$
October 1998, site 4 (WAM T55536); 2 male, same data, 20 - 22 October 2000, site 4 (WAM T56128, T56132); 1 male, same data, 26 - 28 October 2002, site 4 (WAM T58314); 1 female, same data, $28-30$ December 2003, site 4 (WAM T56594); 3 males, same data, $33^{\circ} 54^{\prime} 40^{\prime \prime} \mathrm{S}, 115^{\circ} 00^{\prime} 34^{\prime \prime} \mathrm{E}, 27$ - 28 October 1996, site 5 (WAM 99/26-28); 1 male, same data, 24 - 26 October 1998, site 5 (WAM T55525); 7 males, same data, $33^{\circ} 55^{\prime} 08^{\prime \prime} \mathrm{S}, 115^{\circ} 00^{\prime} 44^{\prime \prime} \mathrm{E}, 13$ - 15 September 1997, site 6 (WAM T55516); 1 female, 2 juv., same data, 27 - 29 December 1997, site 6 (WAM T55518); 2 females, same data, $24-26$ October 1998, site 6 (WAM T55533); 2 males, same data, $20-23$ October 2000, site 6 (WAM T56129); 1 female, same data, 26 - 28 October 2002, site 6 (WAM T58317); 1 female, same data, 28 - 30 December 2003, site 6 (WAM T58318); 1 female, 8 juv., Gleneagle, $32^{\circ} 15^{\prime} \mathrm{S}, 116^{\circ} 10^{\prime} \mathrm{E}, 1971$, J. Springett, Forest Spider Survey 7 (AM KS85112); 1 female,

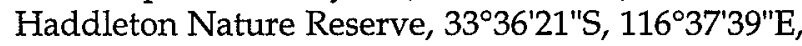
15 October 1999 - 1 November 2000, wet pitfall traps, P. van Heurck et al., CALM Salinity Action Plan, site DA 10 (WAM T56139); 1 male, Helms

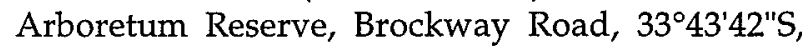
$121^{\circ} 47^{\prime} 50^{\prime \prime} \mathrm{E}, 15$ October 1999 - 1 November 2000, wet pitfall traps, P. van Heurck et al., CALM Salinity Action Plan, site ES 2 (WAM T56168); 3 males, Helms Arboretum Reserve, Shark Lake

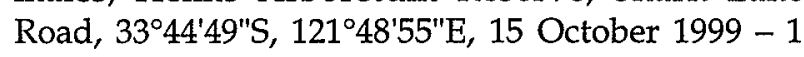
November 2000, wet pitfall traps, P. van Heurck et al., CALM Salinity Action Plan, site ES 1 (WAM T56157); 9 males, 7 females, Hillman Nature

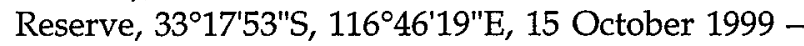
25 May and 2 December 2000, wet pitfall traps, P. van Heurck, CALM Salinity Action Plan, site DA 11, traps 5+5 (WAM T56154); 1 female, 1 juv., King River, Albany, $34^{\circ} 56^{\prime} \mathrm{S}, 117^{\circ} 54^{\prime} \mathrm{E}, 25$ October 1981, D. Hirst (SAM NN13532); 1 male, same data, October 1981 (SAM NN13533); 2 males, 3 females, Kulunilup Nature Reserve, West, $34^{\circ} 20^{\prime} 56^{\prime \prime} \mathrm{S}$, 116²46'21"E, 15 October 1999 - 1 November 2000, wet pitfall traps, P. van Heurck, CALM Salinity Action Plan, site UN 7 (WAM T56135); 2 males,

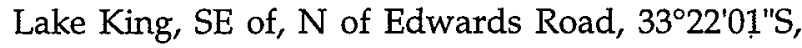
$120^{\circ} 59^{\prime} 43 " \mathrm{E}, 15$ October 1999 - 1 November 2000, wet pitfall traps, P. van Heurck et al., CALM Salinity Action Plan, site GP 2 (WAM T56143); 1 male, Lake Magenta Nature Reserve (S Central), South, 3342'11"S, 118 $58^{\prime} 59^{\prime \prime} \mathrm{E}, 15$ October $1999-1$ November 2000, wet pitfall traps, P. van Heurck et al., CALM Salinity Action Plan, site PI 13 (WAM T56161); 1 female, Lake Muir, $\mathrm{N}$ of, $34^{\circ} 26^{\prime} 35^{\prime \prime} \mathrm{S}$, $116^{\circ} 40^{\prime} 54^{\prime \prime} \mathrm{E}, 15$ October 1999 - 1 November 2000, wet pitfall traps, P. van Heurck et al., CALM Salinity Action Plan, site UN 11 (WAM T56138); 2 females, 16 juv., Margret River area, Burnside, 2$3 \mathrm{~km}$ North of Walcliffe Road, $33^{\circ} 56^{\prime} \mathrm{S}, 115^{\circ} 01^{\prime} \mathrm{E}, 26$ January - 4 March 1979, pitfall trap, M. R. Gray, FN1489, litter (AM KS15119); 8 males, 5 females, 
Metabinup Nature Reserve, North, $34^{\circ} 00^{\prime} 14^{\prime \prime} \mathrm{S}$, 116 50'21"E, 15 October 1999 - 1 November 2000, wet pitfall traps, N. A. Guthrie, CALM Salinity Action Plan, site UN 6 (WAM T56124); 1 male, Metabinup Nature Reserve, South, $34^{\circ} 00^{\prime} 24^{\prime \prime} \mathrm{S}$, $116^{\circ} 50^{\prime} 21^{\prime \prime E}, 15$ October 1999 - 30 May and 1 November 2000, wet pitfall traps, B. Durrant, CALM Salinity Action Plan, site UN 5 (WAM T56125); 1 male, 3 females, Mininup Nature Reserve, 34 $4^{\circ} 06^{\prime} 19^{\prime \prime} \mathrm{S}, 116^{\circ} 49^{\prime} 35^{\prime \prime} \mathrm{E}, 15$ October - 25 May and 1 November 2000, wet pitfall traps, L. King, CALM Salinity Action Plan, site UN 3 (WAM T56134); 1 male, Muir Highway, $N$ of, near Cup Road, 34²3'13"S, 116 30'01"E, 15 October 1999 - 31 October 2000, wet pitfall traps, N. A. Guthrie, CALM Salinity Action Plan, site UN 1 (WAM T56126); 1 female, Muir Highway, $N$ of, near Red Lake Road, 34²5'14"S, 11640'06"E, 15 October 1999 - 31 October 2000, wet pitfall traps, N. A. Guthrie, CALM Salinity Action Plan, site UN 12 (WAM T56151); 5 females, 1 juv., Nornalup-Walpole National Park, Big Tingle Tree, $34^{\circ} 57^{\prime} \mathrm{S}, 116^{\circ} 16^{\prime} \mathrm{E}, 28$ January - 5 March 1979, pitfall trap, M. R. Gray, FN1495, litter (AM KS15419); 9 females, 3 juv., spiderlings, Nornalup-Walpole National Park, Gully Road, $34^{\circ} 58^{\prime} \mathrm{S}, 116^{\circ} 16^{\prime} \mathrm{E}$, 28 January -5 March 1979, pitfall trap, M. R. Gray, FN1496, litter (AM KS15436); 2 females, Ogilvie Road, West, SW Binnu, 27059'19"S, 114²11'40"E, 15 September 1998 - 30 March 1999, wet pitfall traps, P. van Heurck, CALM Salinity Action Plan, site NO 11, traps 1-5 (WAM T56123); 1 female, Pemberton, $34^{\circ} 26^{\prime} \mathrm{S}, 116^{\circ} 02^{\prime} \mathrm{E}, 27$ July 1969, J. A. Springett (WAM T55300); 1 female, 4 juv., same data, 1971, Forest Spider Survey 30 (AM KS85108); 1 male, 1 female, 6 juv., same data, Forest Spider Survey 29, 27 (AM KS85111); 1 female, 7 juv., same data, Forest Spider Survey 29 (AM KS85109); 1 female, same data, Forest Spider Survey 24 (AM KS85110); 1 male, Peringillup

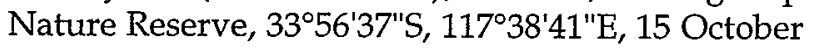
$1999-1$ November 2000, wet pitfall traps, P. van Heurck et al., CALM Salinity Action Plan, site ST 12 (WAM T56136); 21 females, 23 juv., Pine Creek, $0.5 \mathrm{~km}$ from Quarty Road, Nannup-Pemberton area, $34^{\circ} 15^{\prime} \mathrm{S}, 115^{\circ} 50^{\prime} \mathrm{E}, 26$ January -4 March 1979 , pitfall trap, M. R. Gray, FN1491, litter (AM KS15317); 1 female, Porongurup National Park, $34^{\circ} 40^{\prime} 56^{\prime \prime} S$, 117051'59"E, 13 June 1996, wet pitfall traps, S. Barrett, 215, 570m (WAM T53806); 1 female with spiderlings, 7 juv., Porongurup National Park, Bolganup Road, $34^{\circ} 41^{\prime} \mathrm{S}, 117^{\circ} 55^{\prime} \mathrm{E}, 2$ February -6 March 1979, pitfall trap, M. R. Gray, FN1506, in Karri forest litter (AM KS15888); 14 females, 6 juv., Porongurup National Park, Bolganup Road, Hayward Park Trail, $34^{\circ} 41^{\prime} \mathrm{S}, 117^{\circ} 55^{\prime} \mathrm{E}, 2$ February 6 March 1979, pitfall trap, M. R. Gray, FN1509, in Karri forest litter (AM KS15912); 1 male, 1 juv., Porongurup Range, $34^{\circ} 12^{\prime} \mathrm{S}, 117^{\circ} 53^{\prime} \mathrm{E}$, 6 October 1981, D. Hirst (SAM NN13531); 1 female,
Porongurup Range, $34^{\circ} 40^{\prime} \mathrm{S}, 117^{\circ} 50^{\prime} \mathrm{E}, 9$ April 1971, J. A. Springett (WAM T51406); 3 females, Quindinup Nature Reserve, North, $34^{\circ} 24^{\prime} 04^{\prime \prime} S$, 116 $51^{\prime} 48^{\prime \prime E}, 15$ October 1999 - 31 October 2000, wet pitfall traps, P. van Heurck, CALM Salinity Action Plan, site UN 9 (WAM T56150); 12 females, Quindinup Nature Reserve, South, $34^{\circ} 25^{\prime} 46^{\prime \prime} S$, $116^{\circ} 52^{\prime} 45^{\prime \prime} \mathrm{E}, 15$ October 1999 - 31 May and 31 October 2000, wet pitfall traps, B. Durrant, CALM Salinity Action Plan, site UN 10 (WAM T56153); 1 male, 1 juv., Ravensthorpe, $18 \mathrm{~km} \mathrm{~S}, 33^{\circ} 45^{\prime} \mathrm{S}$, $120^{\circ} 02^{\prime} \mathrm{E}, 27$ October 1993, G. Harold, yate woodland (WAM 94/1506-7); 2 males, 1 female,

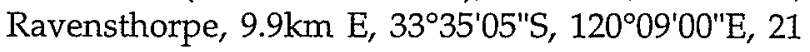
September 1996, pitfall trap, A. Sanders, RA 13 (WAM T56172); 1 male, Speddingup West Road, N

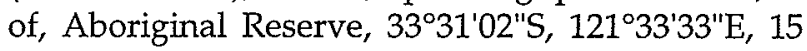
October 1999 - 1 November 2000, wet pitfall traps, P. van Heurck et al., CALM Salinity Action Plan, site GP 9 (WAM T56146); 1 male, 1 female, 1 juv., Stirling Range National Park, East, 34 $17^{\circ} 57^{\prime \prime}$, $118^{\circ} 04^{\prime} 19^{\prime \prime} \mathrm{E}, 15$ October 1999 - 30 May and 30 October 2000, wet pitfall traps, L. King, CALM Salinity Action Plan, site ST 6 (WAM T56152); 12 males, 5 females, Stirling Range National Park, Talyuberlup Picnic Site, $24^{\circ} 24^{\prime} 56^{\prime \prime S}, 117^{\circ} 57^{\prime} 16^{\prime \prime} E, 6$ September - 12 December 1996, M. S. Harvey, J. M. Waldock, B. Y. Main (WAM T55245); 1 male, Stirling Range National Park, Toolbrunup, $34^{\circ} 23^{\prime} 12^{\prime \prime} S, 118^{\circ} 02^{\prime} 48^{\prime \prime} \mathrm{E}$, 15 June 1996, wet pitfall traps, S. Barrett, site 227 (WAM T53834); 3 females, 4 juv., Stirling Range National Park, Toolbrunup Peak Track, $34^{\circ} 24^{\prime} \mathrm{S}, 118^{\circ} 04^{\prime} \mathrm{E}, 10$ June 1993, J. M. Waldock, A. Sampey, Xanthorrhoea litter (WAM 99/ 167-73); 2 males, 1 female, same location, 10 June 21 December 1993, wet pitfall traps, J. M. Waldock, A. Sampey, A. Rose (WAM 99/164-6); 1 female, same location, 31 March 1993, M. S. Harvey, J. M. Waldock, under rocks (WAM T56208); 1 female, 1 female with eggsac, Stirling Range National Park, Toolbrunup walking trail, $34^{\circ} 23^{\prime} 32^{\prime \prime} \mathrm{S}, 118^{\circ} 03^{\prime} 32^{\prime \prime} \mathrm{E}$, 14 December 2001, M. S. Harvey (WAM T55247-8); 8 males, 2 females, Stirling Range National Park, West, 34 $18^{\circ} 01^{\prime \prime} \mathrm{S}, 118^{\circ} 04^{\prime} 03^{\prime \prime} \mathrm{E}, 15$ October $1999-30$ October 2000, wet pitfall traps, N. A. Guthrie, CALM Salinity Action Plan, site ST 5 (WAM T56158); 19 females, 10 juv., Stirling Range National Park, White Gum Flat, $34^{\circ} 22^{\prime} \mathrm{S}, 117^{\circ} 48^{\prime} \mathrm{E}$, 3 February -6 March 1979, pitfall trap, M. R. Gray, FN1512, in White Gum litter (AM KS15939); 1 male, 12 females, Stirling Range National Park, West, 34 ${ }^{\circ} 18^{\prime} 01^{\prime \prime} S$, 11804'03"E, 15 October 1999 - 1 November 2000, wet pitfall traps, P. van Heurck et al., CALM Salinity Action Plan, site ST 5 (WAM T56167); 3 males, 6 females, Tambellup Water Supply Reserve, $34^{\circ} 02^{\prime} 20^{\prime \prime} \mathrm{S}, 117^{\circ} 33^{\prime} 30^{\prime \prime} \mathrm{E}, 15$ October $1999-1$ November 2000, wet pitfall traps, P. van Heurck et al., CALM Salinity Action Plan, site ST 13 (WAM T56169, T56147); 2 females, Tenterden, Pinjalup 
Road, 34⒉ $38^{\prime \prime} \mathrm{S}, 117^{\circ} 33^{\prime} 43^{\prime \prime} \mathrm{E}, 15$ October $1999-1$ November 2000, wet pitfall traps, P. van Heurck et al., CALM Salinity Action Plan, site ST 3 (WAM T56142); 15 females, 1 juv., Treen Brook State Forest, $8 \mathrm{~km} \mathrm{~W}$ of Pemberton, $34^{\circ} 26^{\prime} \mathrm{S}, 116^{\circ} 04^{\prime} \mathrm{E}, 28$ January - 4 March 1979, pitfall trap, M. R. Gray, FN1492, litter (AM KS15336): 6 females, Two People Bay, 34 57'S, $118^{\circ} 09^{\prime} \mathrm{E}, 29$ January - 5 March 1979 , pitfall trap, M. R. Gray, FN1499, litter (AM KS15452); 1 female, 2 juv., Two People Bay area, Ledge Point Beach Road, $34^{\circ} 58^{\prime} \mathrm{S}, 118^{\circ} 02^{\prime} \mathrm{E}, 29$ January - 5 March 1979, pitfall trap, M. R. Gray, FN1498, litter (AM KS15467); 1 female, Two People Bay Reserve, $34^{\circ} 57^{\prime} \mathrm{S}, 118^{\circ} 11^{\prime} \mathrm{E}, 15$ January $1974, \mathrm{M}$. R. Gray, under logs (AM KS69379); 1 male, 10 females, Unicup Nature Reserve, Mordalup Road, $34^{\circ} 19^{\prime} 01^{\prime \prime} \mathrm{S}, 116^{\circ} 31^{\prime} 49^{\prime \prime} \mathrm{E}, 15$ October 1999 - 1 June and 31 October 2000, wet pitfall traps, P. van
Heurck, CALM Salinity Action Plan, site UN 2, traps 5+5 (WAM T56149); 1 female, Walpole, $4 \mathrm{mi}$ W, 34 $58^{\prime} \mathrm{S}, 116^{\circ} 40^{\prime} \mathrm{E}, 22$ October 1969 , R. W. Taylor, ANIC Berlesate No. 143, karri forest, leafmould (ANIC ); 25 females, 9 juv., spiderlings, WalpoleNormalup National Park, Hill Top Road, 34 57'S, $116^{\circ} 15^{\prime} \mathrm{E}, 28$ January - 5 March 1979, pitfall trap, M. R. Gray, FN1494, litter (AM KS15395); Walpole National Park, Hilltop Road, 12 January 1987, R. J. Raven, open forest (QM S13166); 4 males, 1 female, Wansbrough Nature Reserve, West, 34'21'38"S, $117^{\circ} 33^{\prime} 43^{\prime \prime} \mathrm{E}, 15$ October 1999 - 1 November 2000, wet pitfall traps, P. van Heurck et al., CALM Salinity Action Plan, site ST 3 (WAM T56163); 1 female, Wilson Inlet, $34^{\circ} 59^{\prime} \mathrm{S}, 117^{\circ} 22^{\prime} \mathrm{E}, 2$ February 1986, G. Harold, site 1 (WAM T553131); 1 male, 1 juv., Yarina Spring Road, 28 0609'S, 114 $20^{\prime} 06^{\prime \prime} \mathrm{E}$, 30 March - 18 October 1999, wet pitfall traps, L.

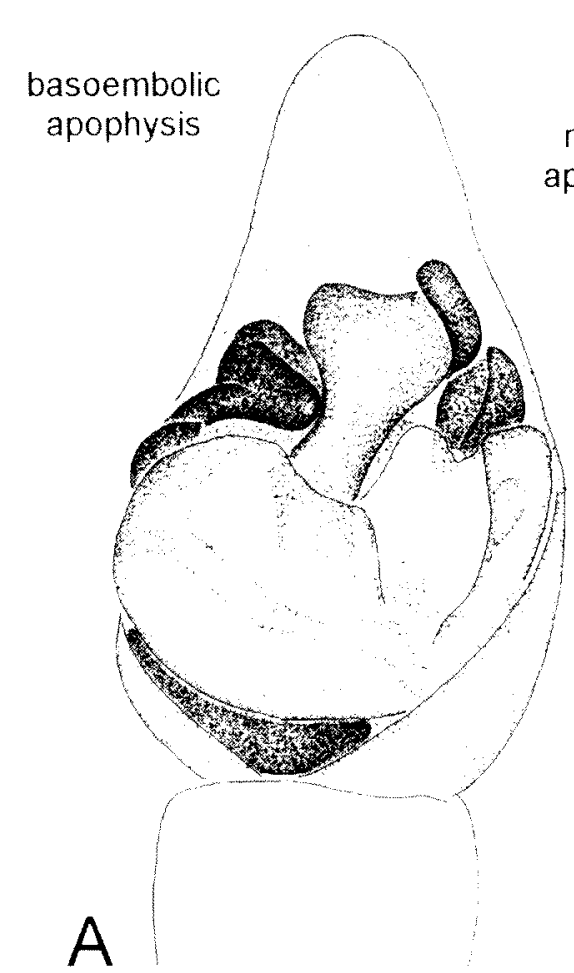

basoembolic apophysis

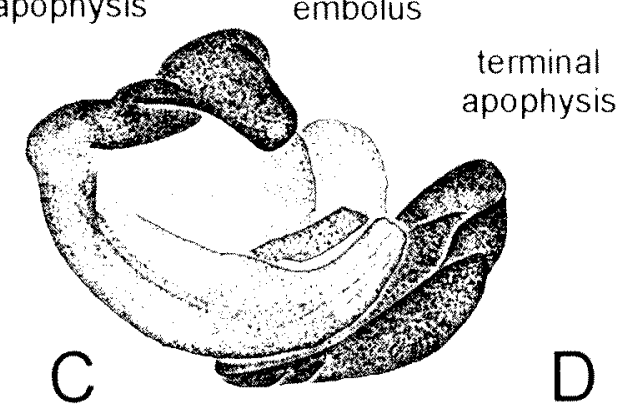

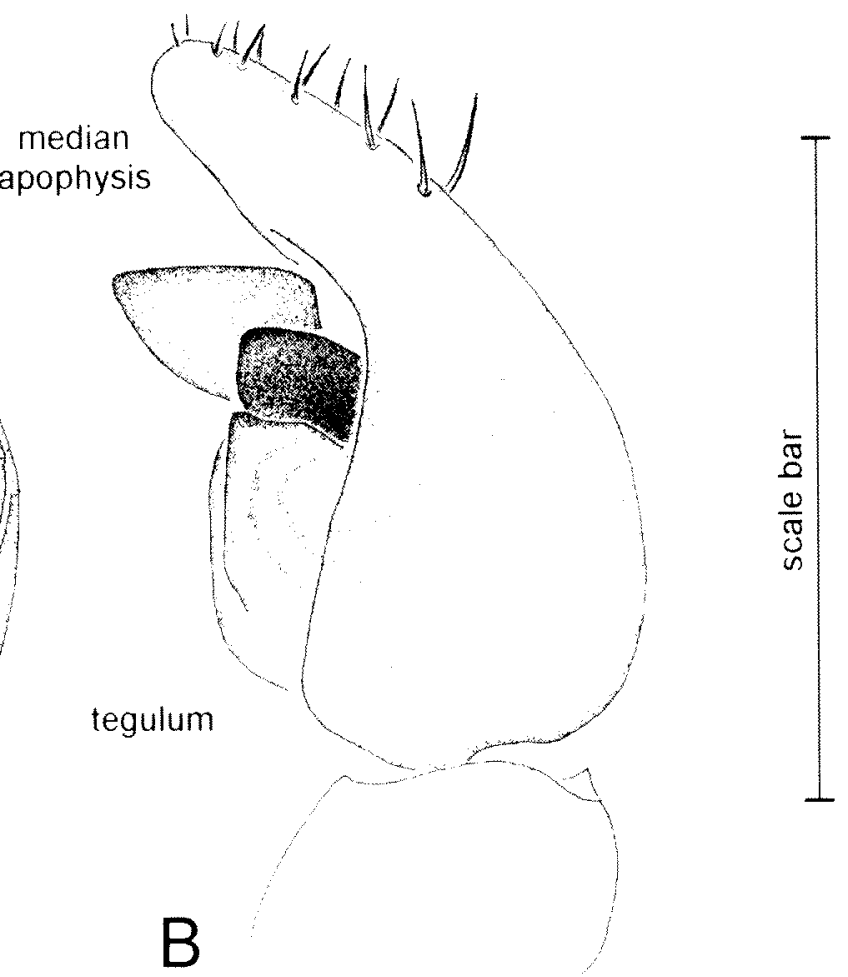

atrium

spermatheca

copulatory

duct

Figure 5 Artoria cingulipes Simon, 1909, male (WAM T56223 from 'Glenbourne' farm, S of Gracetown, Western Australia): A - left pedipalp, ventral view; B - left pedipalp, retrolateral view; $C$ - left pedipalp, apical part of bulbus. Female: D - epigyne (WAM T56224 from 'Glenbourne' farm, $S$ of Gracetown, Western Australia) ventral view; E - epigyne (WAM T56224), dorsal view. Scale bar: A, B - $0.91 \mathrm{~mm}$; C $-0.76 \mathrm{~mm} ; \mathrm{D}, \mathrm{E}-1.53$ $\mathrm{mm}$. 
King, CALM Salinity Action Plan, site NO 12, traps 1-5 (WAM T56162).

\section{Diagnosis}

The morphology of male and female genitalia of $A$. cingulipes is unique amongst the described species of Artoria. However, there are some undescribed species present in Australian collections that closely resemble this species and dissection of the male pedipalp (shape of the terminal apophysis) and female epigyne (shape of spermathecae and copulatory ducts) may be required to accurately identify this species. The male has a very stout embolus resting in a heavily sclerotized terminal apophysis, the female spermathecae form large round spheres and the copulatory ducts are attached laterally.

\section{Description}

Male (based on WAM T56223). Carapace: Very dark brown, posterior flanks darker; head region bordered posteriorly by dark lines that touch in median band; indistinct light brown median and submarginal bands; dark grey radial pattern; carapace covered with few black and white setae, dense white setae on median band; one long brown bristle between AME, two long brown bristles below AE. Sternum: Brown; few black setae increasing in length towards margins. Labium: Dark brown; front end truncate and white. Chelicerae: Dark brown, basally lighter; sparsely covered with white setae of variable length; three retromarginal teeth, with the basal shortest; three promarginal teeth, with the middle largest. Pedipalp (Figures 5AC): Cymbium dorsally with pairs of macrosetae in apical third; median apophysis a curved triangle with ventrally bent tip; terminal apophysis very strong (Figure 5C). Abdomen: Very dark olive-grey with irregular dark patches; covered with whitish and longer black setae; light heart mark in anterior half very distinct through a dense layer of white setae; venter dark brown, lateral borders lighter, two indistinct longitudinal yellow stripes forming a $\mathrm{V}$ that opens anteriorly; covered with whitish and brown setae; spinnerets dark grey. Legs: Leg formula IV > I > II > III; brown, with distinct dark annulations; spination of leg I: Femur: 2 dorsal, 1 apicoprolateral; tibia: 3 ventral pairs, 2 prolateral; metatarsus: 3 ventral pairs, 1 prolateral, 1 retrolateral, 1 apicoventral, 1 apicoprolateral, 1 apicoretrolateral.

Female (based on WAM T56224). Carapace: As male, generally lighter. Sternum: Light brown, some dark pigmentation towards margins; setae as male. Labium: Brown, front end truncate and white. Chelicerae: Dark brown, some grey setae of variable length and few long brown bristles. Epigyne (Figures 5D, E): Ventral view: simple oval atrium

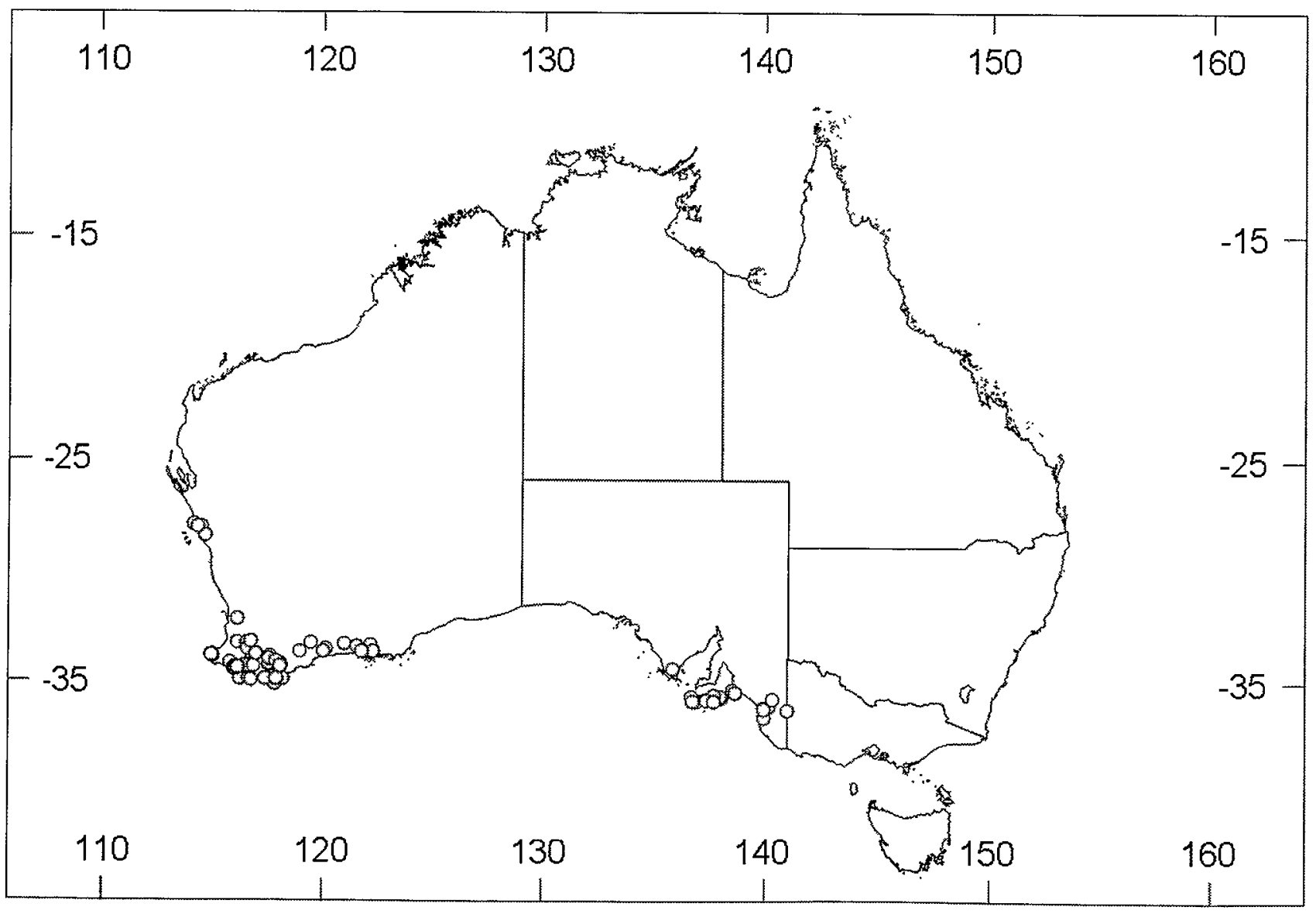

Figure 6 Records of Artoria cingulipes Simon, 1909. 
and light yellow median septum that fills out the whole opening (Figure 5D); dorsal view: distinct bulbous spermathecae, copulatory ducts connected laterally (Figure 5E). Abdomen: Light olive-brown with orange-brown lanceolate heart mark; four additional black patches in posterior half; covered with brown setae; venter yellowish-brown, covered with brown setae; spinnerets yellow-brown. Legs: Leg formula IV > I > II > III; brown, distinct dark annulations less obvious dorsally; spination of leg I: Femur: 3 dorsal, 1 apicoprolateral; tibia: 2 ventral pairs, third pair reduced to 1 apicoventral, 1 prolateral; metatarsus: 3 ventral pairs, 1 apicoventral.

Measurements. Male WAM T56223 (female WAM T56224): TL 5.03 (6.60), CL 3.50 (2.70), CW 2.18 (2.1). Eyes: AME 0.09 (0.07), ALE 0.09 (0.09), PME 0.30 (0.27), PLE 0.21 (0.23). Row of eyes: AE 0.50 (0.53), PME 0.80 (0.77), PLE 0.97 (0.94). Sternum (length/ width) $1.50 / 1.05(1.35 / 0.98)$. Labium (length/ width) $0.37 / 0.37(0.40 / 0.40)$. AL 2.10 (3.75), AW 1.65 (2.55. Legs: Lengths of segments (femur + patella $/$ tibia + metatarsus + tarsus $=$ total length): Pedipalp $0.86+0.87+-+0.94=2.67, \mathrm{I}$ $1.95+2.48+1.52+0.83=6.78$, II $1.88+2.25+1.49+0.74=$ 6.36, III $1.73+2.03+1.58+0.74=6.08$, IV $2.25+2.78+1.8+1.00=7.83$ (Pedipalp 1.09+0.92+ $+0.63=2.64$, I $1.65+2.10+1.20+0.75=5.70$, II $1.65+1.95+1.13+0.75=5.48$, III $1.50+1.65+1.43+0.75$ $=5.33$, IV 2.10+2.63+2.25+0.83 = 7.81).

Variation. Males (females) (range, mean \pm s.d.): TL $3.90-5.70,4.79 \pm 0.50 ; \mathrm{n}=20 ; \mathrm{CL} 2.25-3.00,2.66 \pm$ $0.21 ; \mathrm{n}=20 ; \mathrm{CW} 1.65-2.25,1.93 \pm 0.23 ; \mathrm{n}=20$ (TL $4.35-8.25,6.36 \pm 0.87, \mathrm{n}=20 ; \mathrm{CL} 2.55-3.75,3.08 \pm$ $0.33, \mathrm{n}=20$; CW 1.80-3.00, 2.30 $\pm 0.32 ; \mathrm{n}=20$ ).

\section{Remarks}

The holotype female of $A$. cingulipes was redescribed by Framenau (2002), then the only specimen known of this species. Examination of the collections at the WAM and SAM provided a large amount of material, including males, which are here illustrated for the first time. In addition, the internal genitalia of a representative female are depicted.

Artoria cingulipes appears to prefer open forests and woodlands (e.g. karri, Eucalyptus diversicolor), where it inhabits the ground litter layer. Adult spiders were mainly found in summer, with highest numbers reported between October and December. Occasionally, adults have also been found in June and August.

\section{Distribution}

Coastal Western and South Australia (Figure 6).

Artoria gloriosa (Rainbow, 1920), comb. nov. Figures 7A-F, 8
Lycosa gloriosa Rainbow, 1920: 261-262, plate 30 figures 94-95.- Roewer, 1955: 272; Bonnet, 1957: 2643; McKay, 1973: 379; McKay, 1979a: 238-240, figures 1F-K; McKay, 1985: 77; Platnick, 1989: 371.

Type

Holotype female of Lycosa gloriosa Rainbow, 1920: Lord Howe Island, New South Wales $31^{\circ} 31^{\prime} \mathrm{S}$, $159^{\circ} 04^{\prime}$ E, A. M. Lea, December 1915 - January 1916, SAM NN038. Examined.

\section{Other material examined}

New South Wales, Lord Howe Island: 1 female, 1 female with eggsac, no exact location, no date (AM KS86485-6); 1 male, Anderson Road, south end, $31^{\circ} 30^{\prime} \mathrm{S}, 1^{\circ} 9^{\circ} 04^{\prime} \mathrm{E}, 16$ November $1979, \mathrm{G}$. B. Monteith, QM Berlesate 149, calcareous soil, 40m alt, Pickard veg: DaCt, sieved litter (QM S64113); 1 female, behind Research Station, 31 $31^{\circ} 37^{\prime \prime} \mathrm{S}$, $159^{\circ} 03^{\prime} 58^{\prime \prime} \mathrm{E}, 22$ February 2001, litter trap, J. Tarnawski, LHI/JT/08L, leaf litter in forest (AM KS79096); 1 male, Boat Harbour Beach, E end, $31^{\circ} 33^{\prime} 37^{\prime \prime S}, 1^{\circ} 59^{\circ} 05^{\prime} 53^{\prime \prime} \mathrm{E}, 26$ November - 2 December 2000, pitfall trap, AM CBCR, LHIS032/05 (AM KS76114); 3 males, 1 female, 6 juv., Dawson Point Ridge, summit, $31^{\circ} 30^{\prime} \mathrm{S}, 159^{\circ} 04^{\prime} \mathrm{E}, 7$ November 1979 , G. B. Monteith, QM Berlesate 128, volcanic soil, $150 \mathrm{~m}$ alt, Pickard veg: $\mathrm{DaCt}$, sieved litter (QM S64115); 2 females, Dawsons Point Ridge, E slope,

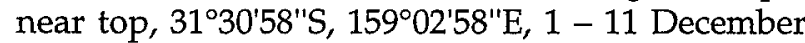
2000, pitfall trap, AM CBCR, LHIS008/02, 05 (AM KS75906, KS75909); 1 male, 1 female, Erskine Valley, trail, 31 $34^{\prime} 37^{\prime \prime} \mathrm{S}, 159^{\circ} 04^{\prime} 33^{\prime \prime} \mathrm{E}, 25$ November - 2 December 2000, pitfall trap, AM CBCR, LHIS045/01, 04 (AM KS76170, KS76175); 1 female, Goat House track, $400 \mathrm{~m}$ from Goat House Cave, $31^{\circ} 33^{\prime} 15^{\prime \prime S}, 159^{\circ} 04^{\prime} 57^{\prime \prime} \mathrm{E}, 23$ February 2001, litter trap, J. Tarnawski, M. Shea, LHI/JT/09LAii, Howea forsteriana, leaf litter (AM KS79103); 1 female, Kims Lookout Trail and North Beach Trail junction,

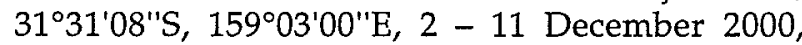
pitfall trap, AM CBCR, LHIS010/03 (AM KS75913); 18 males, 1 female, Lagoon Beach between rubbish tip and airstrip, $31^{\circ} 32^{\prime} 31^{\prime \prime} \mathrm{S}, 159^{\circ} 04^{\prime} 31^{\prime \prime} \mathrm{E}, 27$ November - 4 December 2000, pitfall trap, AM CBCR, LHIS022/01-05 (AM KS75989, KS75996, KS76001, KS76007, KS76010, KS79107); 1 male, 1 female, Lagoon Road, opposite hospital, 31 ${ }^{\circ} 30^{\prime} \mathrm{S}$, $159^{\circ} 04$ 'E, 4 November 1979, G. B. Monteith, QM Berlesate 119, alluvial soil, $2 \mathrm{~m}$ alt, Pickard veg: $\mathrm{DaCt}$, sieved litter (QM S64116); 1 male, same data, QM Berlesate 122 (QM S64119); 1 female, 1 juv., Lagoon Road, $\mathrm{N}$ of Blinky Beach Road turnoff, 3132'30"S, 15904'30"E, 3 February 1971, M. Gray, station 25 (AM KS56); 1 female, Leanda-Lei, behind, $31^{\circ} 30^{\prime}$ S, $159^{\circ} 04^{\prime} E$, November 1979, G. B. Monteith, QM Berlesate 127, calcareous soil, 45m alt, Pickard veg: Hf, sieved litter (QM S64109); 1 female, 13 juv., 
Little Island, beside, $31^{\circ} 30^{\prime} \mathrm{S}, 159^{\circ} 04^{\prime} \mathrm{E}, 7$ November 1979, G. B. Monteith, QM Berlesate 129, volcanic soil, $2 \mathrm{~m}$ alt, Pickard veg: Hf, sieved litter (QM S64118); 2 females, Little Slope, 3135'12'S, 159 04'03'E, 30 November - 7 December 2000, pitfall trap, AM CBCR, LHIS051/03-04 (AM KS76229, KS76231); 1 male, same location, 30 November 2000, beating, AM CBCR, LHIS051L, broad megaphyllous closed sclerophyll forest, Howea belmoryana (AM KS75849); 1 female, Lord Howe Island, $31^{\circ} 30^{\prime} S, 159^{\circ} 04^{\prime} \mathrm{E}, \mathrm{M}$. R. Gray, station 38 , on ground (AM KS55); 2 females, Malabar Ridge

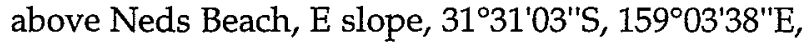
25 November - 2 December 2000, pitfall trap, AM CBCR, LHIS011/01, 03 (AM KS75918, KS75922); 1 male, 2 females, 2 juv., Malabar Ridge Saddle, $31^{\circ} 30^{\prime} \mathrm{S}, 159^{\circ} 04^{\prime} \mathrm{E}, 25$ November 1979 , G. B. Monteith, QM Berlesate 167, volcanic soil, 120m alt, Pickard veg: DaCt, sieved litter (QM S64108); 1 female, 1 juv., Malabar Summit, $31^{\circ} 30^{\prime} \mathrm{S}, 159^{\circ} 04^{\prime} \mathrm{E}$, 25 November 1979, G. B. Monteith, QM Berlesate 168, volcanic soil, $200 \mathrm{~m}$ alt, Pickard veg: $\mathrm{DaCt}$, sieved litter (QM S64110); 1 male, 1 female, Malabar Ridge, W slope, S of Kims Lookout, 31 $30^{\prime} 57^{\prime \prime} S$, 1590331'E, 24 November - 1 December 2000, pitfall trap, AM CBCR, LHIS007/05 (AM KS75899, KS75902); 3 males, Mt Eliza, $50 \mathrm{~m}$ S of summit, W face, 31 30'57'S, $159^{\circ} 02^{\prime} 25^{\prime \prime} \mathrm{E}, 25$ November - 2 December 2000, pitfall trap, AM CBCR, LHIS005/ 01, 04 (AM KS75873, KS75885); 4 males, 1 female, 2 juv., Mt Gower, bottom of ridge, $S$ of igloo, $31^{\circ} 35^{\prime} 08^{\prime \prime S}, 1^{\circ} 04^{\circ} 30^{\prime \prime} \mathrm{E}, 18$ - 31 January 2002, pitfall trap, I. Hutton, MG009 (AM KS85172); 7 males, Mt Gower, bottom of ridge, $\mathrm{N}$ of igloo, $31^{\circ} 35^{\prime} 05^{\prime \prime} \mathrm{S}$, $159^{\circ} 04^{\prime} 34^{\prime \prime E}, 18$ - 31 January 2002, pitfall trap, I. Hutton, MG006 (AM KS85171); 6 males, 3 females, Mt Gower, bottom of ridge, near of igloo, $31^{\circ} 35^{\prime} 04^{\prime \prime S}, 1^{\circ} 09^{\circ} 31^{\prime \prime E}, 18$ - 31 January 2002, pitfall trap, I. Hutton, MG003, ca. 772m (AM KS85174);1 female, $\mathrm{Mt}$ Gower, end of ridge, $31^{\circ} 35^{\prime} 11^{\prime \prime} \mathrm{S}$, $159^{\circ} 04^{\prime} 21^{\prime \prime E}, 18$ - 31 January 2002, pitfall trap, I. Hutton, MG015/01 (AM KS85176); 2 males, 1 female, Mt Gower, midway down gully near igloo, $31^{\circ} 35^{\prime} 06^{\prime \prime S}, 1^{\circ} 09^{\circ} 32^{\prime \prime} \mathrm{E}, 18$ - 31 January 2002, pitfall trap, I. Hutton, MG002, ca 782m (AM KS85170, KS86841); 4 males, Mt Gower, midway down ridge, $\mathrm{N}$ of igloo, $31^{\circ} 35^{\prime} 05^{\prime \prime} \mathrm{S}, 159^{\circ} 04^{\prime} 35^{\prime \prime} \mathrm{E}, 18$ - 31 January 2002, pitfall trap, I. Hutton, ca. 819m, MG005 (AM KS85178); 2 males, 2 females, Mt Gower, midway down large gully with waterfall, $31^{\circ} 35^{\prime} 08^{\prime \prime} S$, $159^{\circ} 04^{\prime} 27^{\prime \prime E}, 18$ - 31 January 2002, pitfall trap, I. Hutton, MG011, ca. 850m (AM KS85175); 10 males, 2 females, Mt Gower, midway down ridge, $\mathrm{S}$ of igloo, 31 $35^{\prime} 09^{\prime \prime} S, 1^{\circ} 04^{\circ} 31^{\prime \prime} \mathrm{E}, 18$ - 31 January 2002, pitfall trap, I. Hutton, MG008, ca. 838m (AM KS85181); 1 male, Mt Gower summit, 31 $35^{\prime} 23^{\prime \prime} \mathrm{S}$, $159^{\circ} 04^{\prime 22}$ 'E, 28 November - 5 December 2000, pitfall trap, AM CBCR, LHIS052/03 (AM KS76235); 1 male, 3 females, 11 juv., Mt Gower summit, NE area, 31 $35^{\prime} 12^{\prime \prime} S, 1^{\circ} 04^{\circ} 42^{\prime \prime E}, 12$ - 15 February 1971, M. Gray, station 45 (AM KS52-4); 1 male, Mt Gower

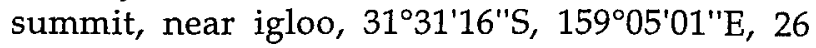
February 2001, litter trap, M. Shea, LHI/MS/07L, leaf litter (AM KS79109); 1 female, Mt Gower

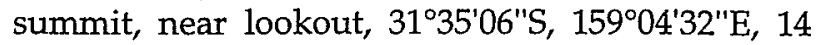
December 2000, H. M. Smith (AM KS70559); 1 male, 9 juv., Mt Gower summit (NE), 31 $30^{\prime} S, 1^{\circ} 09^{\circ} \mathrm{E}, 9$ November 1979, G. B. Monteith, QM Berlesate 133, volcanic soil, $850 \mathrm{~m}$ alt, Pickard veg: GMF, sieved litter (QM S64117); 1 female, same data, QM Berlesate 135 (QM S64114); 1 male, Mt Gower,

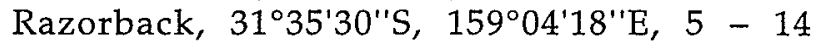
December 2000, pitfall trap, AM CBCR, LHIS056/ 05 (AM KS76249); 1 male, Mt Gower, top of ridge, $S$ of igloo, 31 $35^{\prime} 11^{\prime \prime S}, 159^{\circ} 04^{\prime} 31^{\prime \prime E}, 20$ November 2001, litter trap, I. Hutton, P. Flemons, C. Reid, MG007L (AM KS79104); 1 male, same location, 18 - 31 January 2002, pitfall trap, I. Hutton, MG007 (AM KS85180); 21 males, 1 female, Mt Gower, top of gully, $\mathrm{N}$ or igloo, $31^{\circ} 34^{\prime} 02^{\prime \prime} \mathrm{S}, 159^{\circ} 04^{\prime} 05^{\prime \prime} \mathrm{E}, 18-31$ January 2002, pitfall trap, I. Hutton, MG005, ca. 824m (AM KS84008); 5 males, 1 female, Mt Gower, top of gully, near igloo, 31 $34^{\prime} 027^{\prime \prime} S, 159^{\circ} 04^{\prime} 35^{\prime \prime} \mathrm{E}, 18$ - 31 January 2002, pitfall trap, I. Hutton, MG001, ca. 802m (AM KS85179); 1 male, Mt Lidgbird, 30m

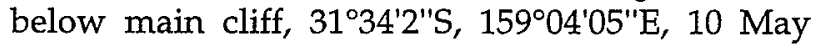
2001, litter trap, I. Hutton, IH009B, leaf litter, 380m (AM KS79105); 1 male, Mt Lidgbird, E face, base of summit plateau, $31^{\circ} 34^{\prime} 27^{\prime \prime S}, 159^{\circ} 05^{\prime} 04^{\prime \prime} \mathrm{E}, 3$ December 2000, litter trap, AM CBCR, LHIS039L, ex closed rainforest, Cryptocarya gregsonii (AM KS75822); 1 female, same location, December 2000, AM CBCR, LHISO39, closed rainforest, CleistocalyxChionanthus (AM KS73167); 2 males, 2 females, Mt Lidgbird, Far Flats, base of Round Face, 31 $34^{\circ} 09^{\prime \prime} S$, 159 04'35'E, 27 November - 4 December 2000, pitfall trap, AM CBCR, LHIS036/02-04 (AM KS76127, KS76134, KS76136); 7 males, 1 female, same location, 4 - 14 December 2000, pitfall trap, AM CBCR, LHIS036/01, 02-04 (AM KS79097, KS76126, KS76128, KS76131, AM KS79108); 1 male, Mt Lidgbird, footslopes, $200 \mathrm{~m} \mathrm{E}$ of Goat House

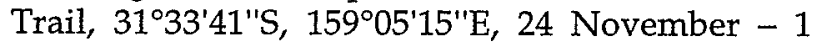
December 2000, pitfall trap, AM CBCR, LHIS029/ 05 (AM KS76084); 1 male, Mt Lidgbird, S face, summit tabletop base, $31^{\circ} 34^{\prime} 37^{\prime \prime} \mathrm{S}, 159^{\circ} 05^{\prime} 04^{\prime \prime} \mathrm{E}, 26$ November - 3 December 2000, pitfall trap, AM CBCR, LHIS044/01 (AM KS76166); 1 male, Peach Tree Ridge, below Intermediate Hill, 31 $33^{\prime} 01^{\prime \prime} \mathrm{S}$, $159^{\circ} 05^{\prime} 05^{\prime \prime} \mathrm{E}, 3$ - 13 December 2000, pitfall trap, AM CBCR, LHIS023/02 (AM KS76026); 2 females, Phillip Point (North Head), E slope, 31 $31^{\prime} 20^{\prime \prime} \mathrm{S}$, $159^{\circ} 02^{\prime} 29^{\prime \prime} \mathrm{E}, 24$ November - 1 December 2000, pitfall trap, AM CBCR, LHIS015/01 (AM KS75937); 1 female, Roach Island, E slopes, 31 $30^{\prime} 08^{\prime \prime} \mathrm{S}$, $159^{\circ} 04^{\prime} 09^{\prime} \mathrm{E}$, 29 November - 7 December 2000, pitfall trap, AM CBCR, LHIS003/03 (AM KS75866); 1 male, Rocky Run Creek, $\mathrm{N}$ bank, Boat Harbour 
trail, 31 33'19'S, $159^{\circ} 05^{\prime} 33^{\prime \prime} \mathrm{E}, 3$ - 13 December 2000, pitfall trap, AM CBCR, LHIS024/05 (AM KS76059); 1 female, Salmon Beach, $\mathrm{S}$ end, 31 $34^{\prime} 08^{\prime \prime} \mathrm{S}$, $159^{\circ} 04^{\prime} 28^{\prime \prime} \mathrm{E}, 27$ November 2000, litter trap, AM CBCR, LHIS035L, ex narrow closed sclerophyll forest, Howea forsteriana (AM KS75816); 2 males, 1 female, same location, $4-14$ December 2000 , pitfall trap, AM CBCR, LHIS35/01, 05 (AM KS79098-9, KS79110); 7 males, 1 female, Stephens Reserve, New Settlement, $31^{\circ} 31^{\prime} 33^{\prime \prime} \mathrm{S}, 159^{\circ} 03^{\prime} 53^{\prime \prime} \mathrm{E}, 4-14$ December 2000, pitfall trap, AM CBCR, LHIS059/ 01-04 (AM KS76253-4, KS76263, KS76268, KS762701); 1 female, 2 juv., The Clear Place, $31^{\circ} 30^{\prime} \mathrm{S}$, $159^{\circ} 04 \mathrm{E}$, 22 November 1979, G. B. Monteith, QM Berlesate 157, calcareous soil, $30 \mathrm{~m}$ alt, Pickard veg: Hf and DaCt, sieved litter (QM S64112); 1 male, The Saddle, Erskine Valley, 31 $34^{\prime} 49^{\prime \prime} S, 159^{\circ} 04^{\prime} 58^{\prime \prime} \mathrm{E}, 25$ November - 2 December 2000, pitfall trap, AM CBCR, LHIS046/05 (AM KS76190); 1 male, track to
Erskine Valley, opposite Salmon Beach, $31^{\circ} 33^{\prime} 39^{\prime \prime} \mathrm{S}$, 159 04'31'E, 10 December 2000, litter trap, G. Cassis, LHI/GC/L18, leaf litter (AM KS79106); 3 males, 3 females, trail to Mt Gower, 31 $35^{\circ} 06^{\prime \prime} S$, $159^{\circ} 04^{\prime 4} 5^{\prime \prime} \mathrm{E}, 28$ November - 5 December 2000 , pitfall trap, AM CBCR, LHIS049/02-3 (AM KS76211, KS76213, KS79101); 1 female, same location, 5 - 14 December 2000, pitfall trap, AM CBCR, LHIS049/01 (AM KS76208); 5 males, trail to Mt Gower, $31^{\circ} 35^{\prime} 12^{\prime \prime} S, 159^{\circ} 04^{\prime} 35^{\prime \prime} \mathrm{E}, 28$ November 5 December 2000, pitfall trap, AM CBCR, LHIS050/ 02, 05 (AM KS76218, KS76227); 4 males, same location, 5 - 14 December 2000, pitfall trap, AM CBCR, LHIS050/03-04 (AM KS76219, KS76223, KS79100); 1 male, 2 females, trail to Mt Gower, base of Scaly Bark Ridge, $31^{\circ} 34^{\prime} 37^{\prime \prime} S, 1^{\circ} 9^{\circ} 04^{\prime} 40^{\prime \prime} \mathrm{E}, 25$ November - 2 December 2000, pitfall trap, AM CBCR, LHIS047/01, 05 (AM KS76192, KS79102); 2 males, 1 female, 1 female with spiderlings, same

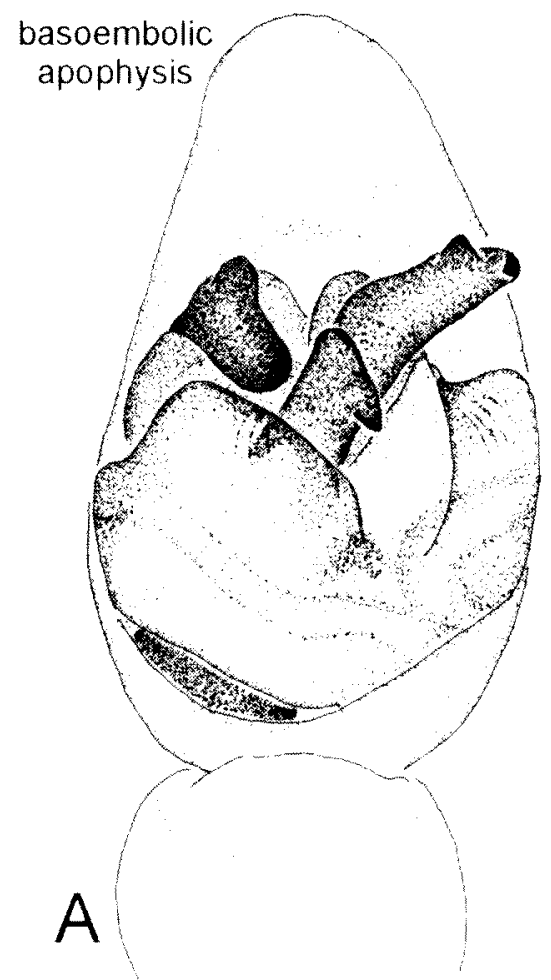

median

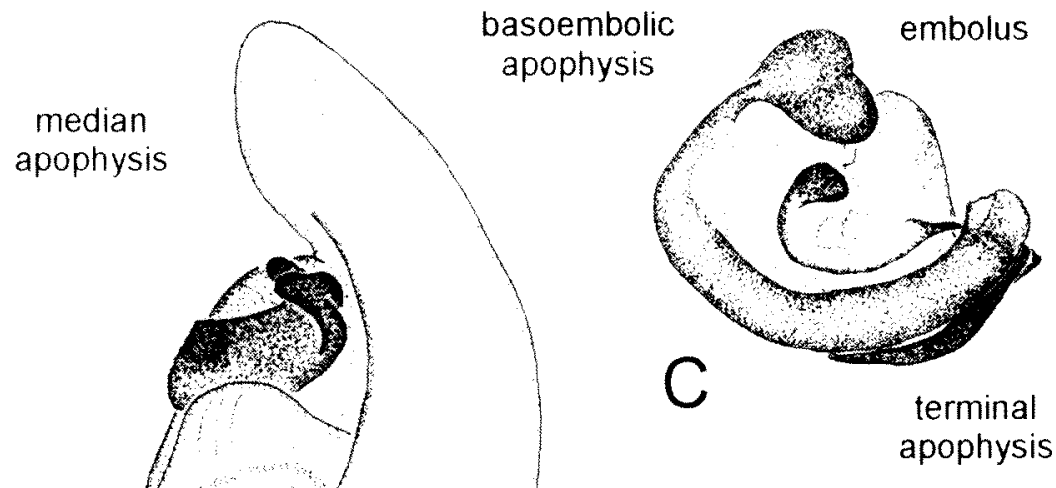

tegulum

septum
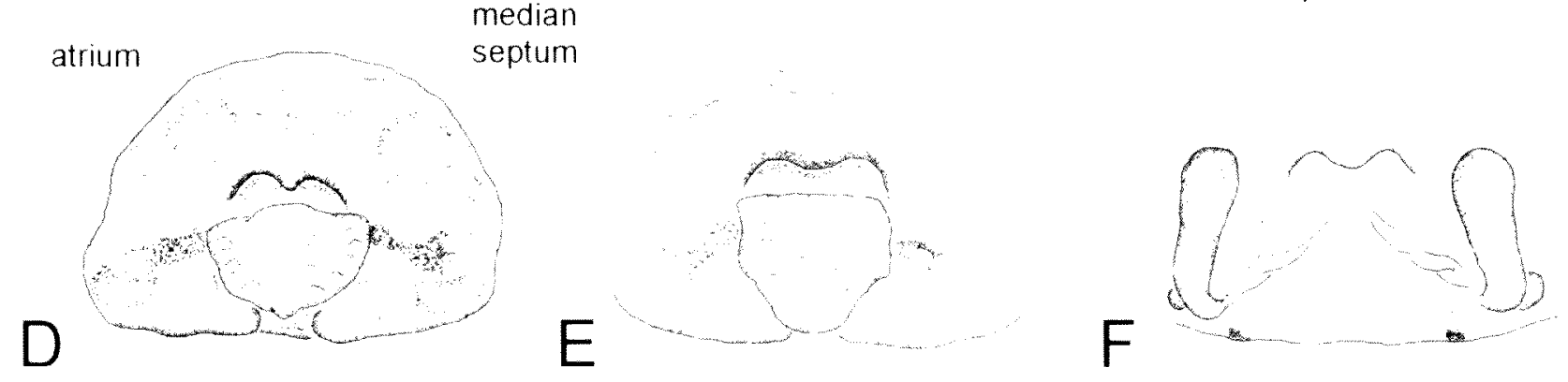

Figure 7 Artoria gloriosa (Rainbow, 1920), male (AM KS86841 from Mt Gower, Lord Howe Island, New South Wales): A - left pedipalp, ventral view; B - left pedipalp, retrolateral view; $C$ - left pedipalp, apical part of bulbus. Female: D - epigyne of holotype (SAM038 from Lord Howe Island, New South Wales), ventral view; E epigyne (AMKS85170 from Mt Gower, Lord Howe Island, New South Wales), ventral view; F - epigyne (AMKS85170), dorsal view. Scale bar: A, B $-0.55 \mathrm{~mm}$; C $-0.63 \mathrm{~mm} ; \mathrm{D}, \mathrm{E}, \mathrm{F}-0.57 \mathrm{~mm}$. 
location, 2 - 11 December 2000, pitfall trap, AM CBCR, LHIS047/02-04 (AM KS76197, KS76200-1); 1 female with spiderlings, Transit Hill, $W$ slope, 31 $32^{\circ} 05^{\prime \prime S}, 159^{\circ} 02^{\prime 24}$ "E, 24 November - 1 December 2000, pitfall trap, AM CBCR, LHIS017/01 (AM KS75942); 1 female, Transit Hill, south slope, $31^{\circ} 30^{\prime} \mathrm{S}, 1^{\circ} 9^{\circ} 04^{\prime} \mathrm{E}, 18$ November $1979, \mathrm{G} . \mathrm{B}$. Monteith, QM Berlesate 152, volcanic soil, $90 \mathrm{~m}$ alt, Pickard veg: DaCt, sieved litter (QM S64111).

\section{Diagnosis}

Artoria gloriosa is very similar to A. albopilata. However, the median apophysis of the male pedipalp of $A$. gloriosa lacks the apical lower tip that is present in $A$. albopilata. In addition, the tip of the embolus of $A$. gloriosa is blunt, whereas it is sharp and sickle-shaped in $A$. albopilata. The median septum of the female epigyne of $A$. gloriosa does not fill out the whole atrium as in $A$. albopilata, but is truncated anteriorly.

\section{Description}

Male (based on KS86841). Carapace: Dark brown, head and posterior flanks darker; distinct light brown median band anteriorly as wide as PLE, narrowest around fovea; indistinct brown submarginal bands; indistinct dark grey radial pattern; carapace covered with black setae, white setae in head region and on median band, black bristles between and lateral of eyes and medially between eyes and fovea, one long brown bristle between AME, two long brown bristles below AE. Sternum: Brown; brown bristles increasing in length towards margins. Labium: Dark brown; front end truncate and white. Chelicerae: Dark brown; sparsely covered with brown setae, particularly long mediobasally; four retromarginal teeth, with the two median slightly larger; three promarginal teeth, with the middle largest. Pedipalp (Figures 7A-C): Median apophysis with double tip and longitudinal ridge in basal half; embolus blunt (Figure 7C). Abdomen: Dark olive-grey and covered with black setae; yellowbrown, lanceolate heart mark in anterior half; indistinct darker irregular patches; four larger patches in a rectangle in posterior half, two light patches between the lateral of the four black patches; venter brown, lateral borders lighter; spinnerets brown. Legs: Leg formula IV > I > II > III; brown, with dark annulations in particular ventrally; spination of leg I: Femur: 3 dorsal, 1 (small) retrolateral, 1 prolateral; tibia: 4 ventral pairs, 2 prolateral; metatarsus: 3 ventral pairs, 3 prolateral.

Female (based on AM KS85170). Carapace: As male, generally lighter, submarginal bands less distinct. Sternum: Yellow-brown, brown bristles increasing in length towards margins. Labium and chelicerae: as male, slightly lighter. Epigyne (Figures 7D-F): Ventral view: simple atrium, anterior border

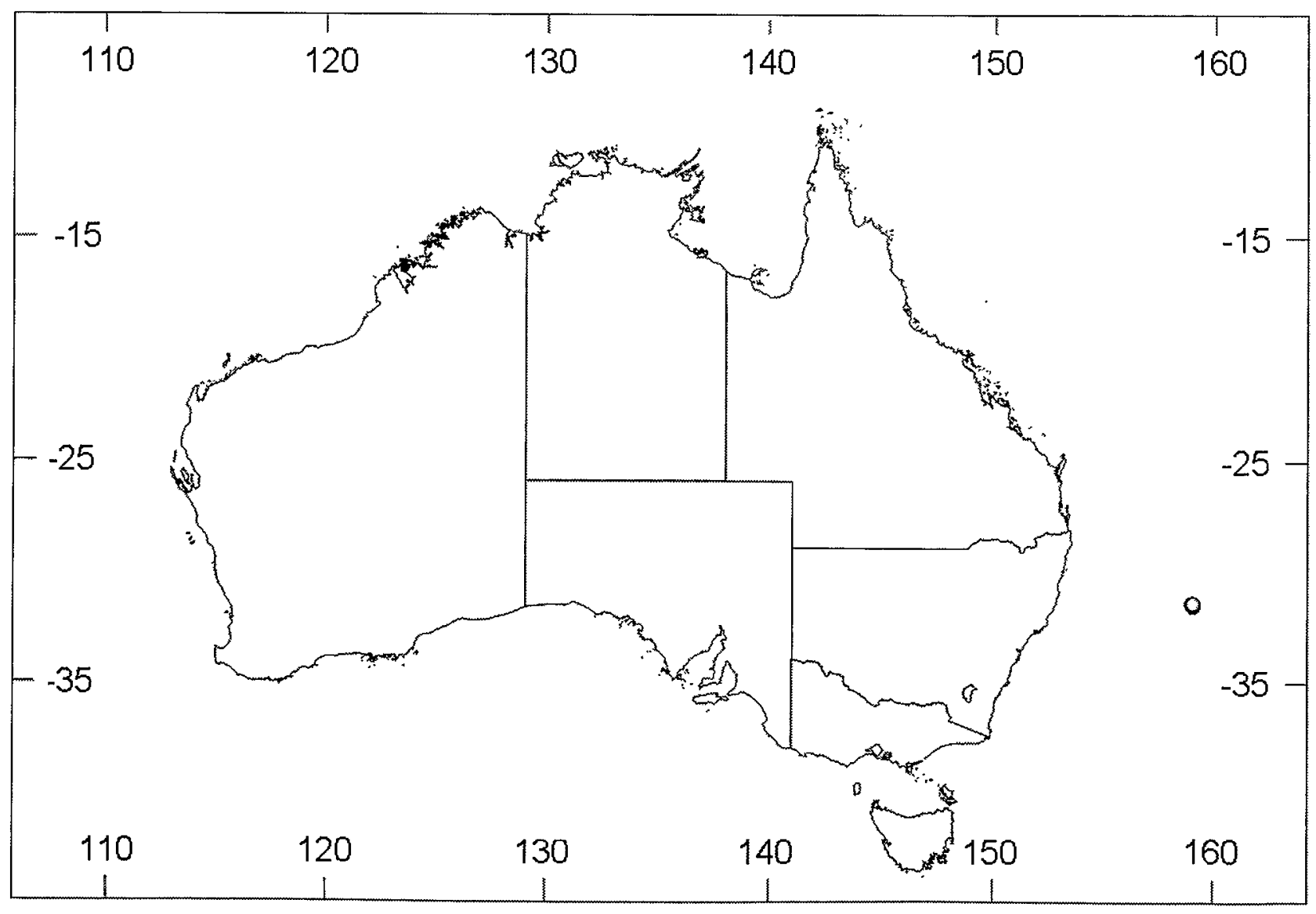

Figure 8 Records of Artoria gloriosa (Rainbow, 1920). 
undulating, median septum truncated anteriorly (Figures 7D, E); dorsal view: indistinct spermathecae, copulatory ducts directed anteriorly (Figure 7F). Abdomen: As male but much lighter (light brown) and therefore colouration more distinct; no light patches between posterior black patches; venter yellow-brown, brown setae; spinnerets yellow. Legs: Leg formula IV > I > III > II; light brown, indistinct dark annulations; spination of leg I: Femur: 3 dorsal, 1 prolateral; tibia: 4 ventral pairs, 2 prolateral, 2 retrolateral; metatarsus: 3 ventral pairs, 3 prolateral, 3 retrolateral.

Measurements. Male AM KS86841 (female AM KS85170): TL 7.35 (9.45), CL 3.68 (4.5), CW 2.93 (3.75). Eyes: AME 0.07 (0.07), ALE 0.09 (0.11), PME 0.22 (0.37), PLE $0.26(0.27)$. Row of eyes: AE 0.62 (0.74), PME 0.89 (1.00), PLE 1.12 (1.27). Sternum (length/width) 1.65/1.5 (1.95/1.8). Labium (length/ width) $0.49 / 0.49$ (0.69/0.63). AL 3.3 (4.95), AW 2.1 (3.45). Legs: Lengths of segments (femur + patella/ tibia + metatarsus + tarsus $=$ total length): Pedipalp $1.28+1.20+-+1.17=3.65$, I $2.40+3.30+1.95+1.13=$ 8.78 , II $2.4+3.08+1.95+1.13=8.56$, III $2.25+2.78+1.95+1.13=8.11$, IV $2.93+3.60+3.45+1.43$ $=11.41$ (Pedipalp 1.58+1.65 $+-+1.13=4.36$, I $2.85+3.68+1.95+1.28=9.76$, II $2.70+3.45+1.95+1.20=$ 9.30 , III $2.7+3.15+2.40+1.20=9.45$, IV $3.60+3.98+3.75+1.65=12.98)$.

Variation. Males (females) (range, mean \pm s.d.): $\mathrm{TL}$ $3.75-9.15,6.21 \pm 1.16 ; \mathrm{n}=37 ; \mathrm{CL} 2.40-4.05,3.27 \pm$ $0.50 ; \mathrm{n}=37 ; \mathrm{CW} 1.65-3.60,2.47 \pm 0.48 ; \mathrm{n}=37(\mathrm{TL}$ $4.5-12.15,8.94 \pm 2.16 \mathrm{n}=19 ;$ CL $2.55-5.70,4.35 \pm$ $1.05, \mathrm{n}=19 ; \mathrm{CW} 1.80-4.35,3.30 \pm 0.88 ; \mathrm{n}=19$ ).

The colouration of $A$. gloriosa can be quite variable from plain brown to more distinctly coloured specimens that may have some white patches as described for the male above. Some specimens have only three retromarginal teeth and three ventral pairs of spines on tibia I. There is also a distinct variation in size. Very small spiders do not have the median band on the carapace but are uniformly dark brown.

\section{Remarks}

McKay (1979a) redescribed A. gloriosa but he illustrated the male pedipalp only in its expanded condition. Consequently, his description did not allow an accurate identification of males without dissecting their genitalia. The pedipalp morphology of A. gloriosa with its strong basoembolic apophysis clearly identifies this species as an Artoria and consequently it is here transferred from Lycosa.

The species appears to be summer-mature. Most adults have been found between November and January.

\section{Distribution}

Artoria gloriosa is only known from Lord Howe Island (Figure 8).
Artoria impedita (Simon, 1909), comb. nov. Figures $9 \mathrm{~A}-\mathrm{F}, 10$

Lycosa impedita Simon, 1909: 187-188, figure 6.Rainbow, 1911: 269; Bonnet, 1957: 2646; McKay, 1973: 379; Moritz, 1992: 316.

Allocosa impedita (Simon).--Roewer, 1955: 206.

Trochosa expolita impedita (Simon).- McKay, 1979b: 288-290, figures 3G-I, N-O (misidentification, not Lycosa impedita sensu Simon, 1909, but Trochosa expolita sensu L. Koch, 1877); McKay, 1985: 86; Platnick, 1989: 391.

\section{Type}

Holotype female of Lycosa impedita Simon, 1909: Gooseberry Hill, Western Australia, 31 ${ }^{\circ} 57^{\prime}$, , $116^{\circ} 03^{\prime} \mathrm{E}, \mathrm{W}$. Michaelsen, R. Hartmeyer ('Hamburger Süd-West Australische Expedition'), Station 152 (Michaelsen and Hartmeyer (1907), from German: ' 31 May 1905, mountainous bushland with creeks, alt. 238m, Darling Ranges'), ZMB 11076. Examined.

\section{Other material examined}

Western Australia: 7 males, 1 female, Buntine Nature Reserve, 29 $58^{\prime} 16^{\prime \prime} \mathrm{S}, 116^{\circ} 35^{\prime} 05^{\prime \prime} \mathrm{E}, 15$ September 1998 - 7 April and 25 October 1999, wet pitfall trap, B. Durrant, CALM Salinity Action Plan, site WU3 (WAM T47374); 1 female, 1 juv., Kwolyin Hill, 31 $51^{\prime} 28^{\prime \prime}$, $117^{\circ} 46^{\prime} 54^{\prime \prime E}, 7$ July 2004, M. S. Harvey, J. M. Waldock, R. Engel, granite outcop, under granite rocks (WAM T58487); 2 females, Kwolyin, ca. 15km NW, Munyard Road, 31'51'56"S, $117^{\circ} 36^{\prime} 39^{\prime \prime E}, 7$ July 2004, M. S. Harvey, J. M. Waldock, R. Engel, granite outcrop (WAM T58485); 3 males, 3 females, 1 juv., Lake Ninan Shire Reserve East, 3057'09"S, 116 39'29"E, 15 September 1998 28 April and 25 October 1999, wet pitfall trap, B. Durrant, CALM Salinity Action Plan; site WH1, traps 1-5 (WAM T47367); 1 male, Mackie Creek Reserve, 31⒌'33"S, $117^{\circ} 01^{\prime} 19^{\prime \prime} \mathrm{E}, 20$ May - 5 November 1998, wet pitfall trap, B. Durrant, CALM Salinity Action Plan; site YO1, traps 1, 5, 7, 9, 10 (WAM T47370); 1 male, Moorajin Soak Nature Reserve, 30 $45^{\prime} 17^{\prime \prime} \mathrm{S}, 17^{\circ} 14^{\prime} 30^{\prime \prime} \mathrm{E}, 15$ September 1998 - 18 October 1999, wet pitfall trap, N. A. Guthrie, CALM Salinity Action Plan, site WH13, traps 1-5 (WAM T47369); 1 male, 2 females, Mt Caroline Nature Reserve, $31^{\circ} 47^{\prime} 36^{\prime \prime S}, 117^{\circ} 38^{\prime} 34^{\prime \prime}$, 7 July 2004 , M. S. Harvey, J. M. Waldock, R. Engel, under granite rock (WAM T58484, T58493); 1 female, Mt Hampton Nature Reserve Dam, $31^{\circ} 45^{\prime} 40^{\prime \prime} \mathrm{S}$, 11904'21"E, 30 October 1997 - 28 April 1998, wet pitfall trap, P. van Heurck et al., CALM Salinity Action Plan, site MN6 (WAM T47372); 1 female, Mt Sterling Nature Reserve, $31^{\circ} 49^{\prime} 59^{\prime \prime} \mathrm{S}, 117^{\circ} 35^{\prime} 41^{\prime \prime} \mathrm{E}, 7$ July 2004, M. S. Harvey, J. M. Waldock, R. Engel, under granite rocks (WAM T58486); 1 female, near 
Holt Rock, $32^{\circ} 40^{\prime} \mathrm{S}, 119^{\circ} 24^{\prime} \mathrm{E}$, September 1971, G. Harold, limestone breakaway (WAM T51402); 1 male, 3 females, Nokaning Rock, $\mathrm{N}$ of Nukarni West Road, ca. 26km NW Merredin, 31'19'52"S, $118^{\circ} 04^{\prime} 25^{\prime \prime E}, 9 / 07 / 2004$, J. M. Waldock, R. Engel, under granite slabs on rock (WAM T58489-90); 1 male, 2 females, Totadgin Rock Conservation Reserve, $31^{\circ} 34^{\prime} 15^{\prime \prime} \mathrm{S}, 118^{\circ} 12^{\prime} 58^{\prime \prime} \mathrm{E}, 10$ July 2007 , J. M. Waldock, R. Engel, under granite slabs on rock (WAM T58488); 1 male, 1 juv., Wambyn Nature Reserve, 31 ${ }^{\circ} 53^{\prime} 46^{\prime \prime S}, 116^{\circ} 37^{\prime 2} 5^{\prime \prime E}, 20$ May - 29 September 1998, wet pitfall trap, B. Durrant, CALM Salinity Action Plan, site YO11, traps 1, 2, 5, 7, 8 (WAM T47373); 2 males, Yenyenning Lakes, $32^{\circ} 13^{\prime} 38^{\prime \prime S}, 117^{\circ} 13^{\prime} 08^{\prime \prime} \mathrm{E}, 20$ May - 5 October 1998, wet pitfall trap, B. Durrant, CALM Salinity Action Plan, site QU7, traps 2, 3, 4, 6, 7 (WAM T47368,
T47371); 1 male, 2 females, Yorkrakine Rock, $41^{\circ} 25^{\prime}$ S, $117^{\circ} 30^{\prime \prime}$ E, 29/04/2004, J. M. Waldock, M. S. Harvey, R. Engel, granite outcrop (WAM T58460-1).

\section{Diagnosis}

The male pedipalp with a gaping bifurcate median apophysis is most similar to that of A. avona Framenau 2002, however, it is overall wider. The female epigyne with its distinct median septum resembles that of $A$. avona but also $A$. flavimana Simon, 1909. However, the epigyne opening of $A$. avona is narrow with parallel lateral borders but triangular and widening posteriorly in A. impedita. The median septum in A. flavimana is usually pentagonal (sometimes triangular), whereas it is rectangular in $A$. impedita.

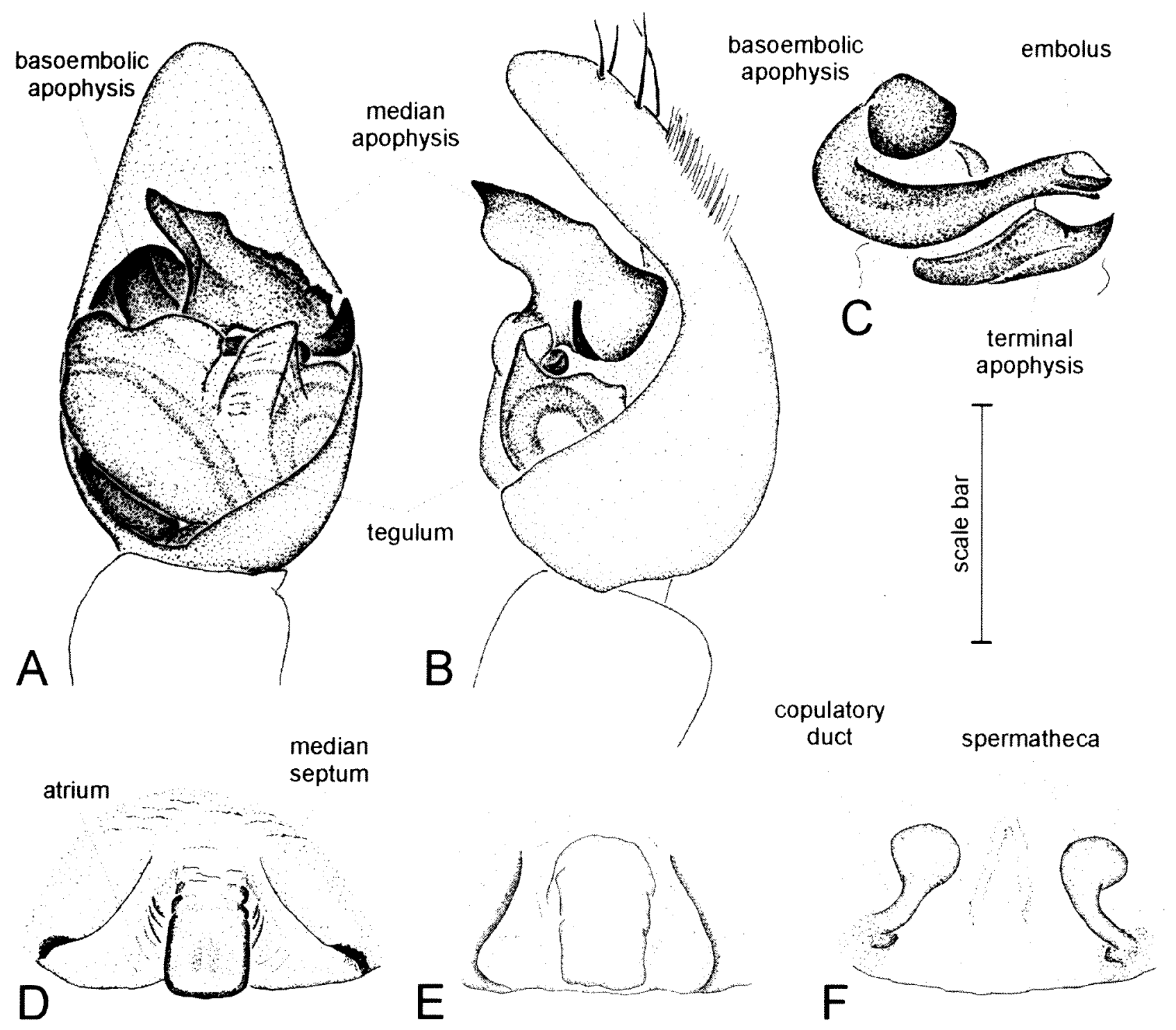

Figure 9 Artoria impedita (Simon, 1909), male (WAM T58460 from Yorkrakine, Western Australia): A - left pedipalp, ventral view; B - left pedipalp, retrolateral view; $C$ - left pedipalp, apical part of bulbus. Female holotype (ZMB 11076 from Goosberry Hill, Western Australia): D - epigyne, ventral view. Female (WAM T51402 from near Holt Rock, Western Australia): E - epigyne, ventral view, F- epigyne, dorsal view. Scale bar: A, B - 0.47 $\mathrm{mm} ; \mathrm{C}-0.40 \mathrm{~mm}$; D, E, F - $0.42 \mathrm{~mm}$. 


\section{Description}

Male (based on WAM T58460). Carapace: Very dark brown, wide and distinct yellow-brown median band with irregular lateral borders, constricted and narrower behind fovea; remnants of ligh brown submarginal bands; carapace covered with black setae, white setae in median band, head region and very few towards lateral carapace margins; one long brown bristle between AME, two long brown bristles below AE. Sternum: Shiny grey pigmented, margins with yellow-brown narrow rim; black bristles mainly towards margins. Labium: Dark brown; front end truncate and white. Chelicerae: Brown, basal third light brown; sparsely covered with black setae, few white setae basally and laterally; three retromarginal teeth, with the basal smallest; three promarginal teeth, with the middle largest. Pedipalp (Figures 9A-C): Median apophysis wide gaping bifurcate with serrated apical edge; embolus strong and blunt (Figure 9C). Abdomen: Dark olive-grey and covered with silverish setae; distinct yellow-brown lanceolate heart mark covered with white setae; venter yellow; spinnerets light brown. Legs: Leg formula IV > I > II $>$ III; very light brown, with distinct dark annulations in particular on femora; spination of leg I: Femur: 3 dorsal, 1 retrolateral, 1 apicoprolateral; tibia: 3 ventral pairs, 2 prolateral, 2 retrolateral; metatarsus: 3 ventral pairs, 2 prolateral, 2 retrolateral (only 1 on left leg), 1 apicoventral, 1 apicoprolateral, 1 apicoretrolateral.

Female (based on holotype). Carapace: Brown, with distinct yellow-brown median band of two-fifth carapace width but constricting posteriorly of fovea; indistinct light brown submarginal bands; head region black; dark grey radial pattern; carapace covered with brown setae in dark parts and white setae in median and submarginal bands; few long brown bristles lateral of PE and above AME; two very long bristles below AME. Sternum: Yellowbrown with dark grey pigmentation; few brown bristles marginally mainly in anterior half. Labium: Brown; front end truncate and white. Chelicerae: Massive; uniformly brown; few brown bristles of various length in basal half; three retromarginal teeth, with the apical largest; three promarginal teeth, with the middle largest. Epigyne (Figures 9DF): Ventral view: triangular opening, wider than long, with rectangular median septum; dorsal view (WAM T51402): Bulbous spermathecae; copulatory ducts directed anteromedially and connected to the spermathecae posteriorly (Figure 9F). Abdomen: Olive-grey, darker medially; very distinct yellow lanceolate heart mark in anterior half; indistinct pattern of grey wedges in posterior half; covered with few brown setae; venter yellow, few light setae; all spinnerets yellow. Legs: Leg formula IV > I $>$ III > II; light brown, distinct annulations on

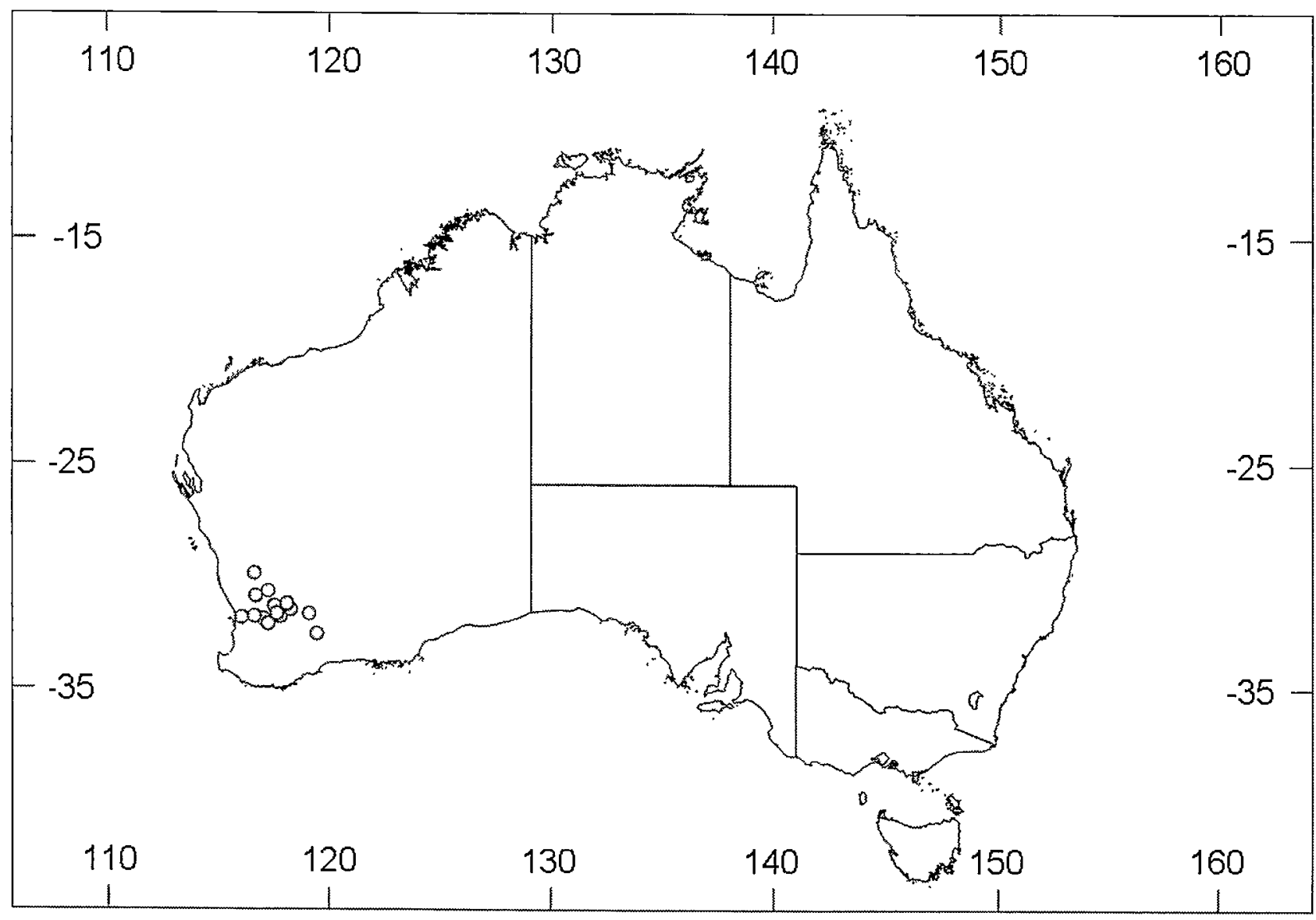

Figure 10 Records of Artoria impedita (Simon, 1909). 
femora and tibae, in particular ventrally; spination of leg I: Femur: 3 dorsal, 1 apicoprolateral; 1 apicoretrolateral, 1 retrolateral; tibia: 3 ventral pairs, 2 prolateral; metatarsus: 3 ventral pairs, 1 prolateral, 1 apicoprolateral, 1 apicoretrolateral, 1 apicoventral.

Measurements. Male WAM T58460 (Female holotype ZMB 11076): TL 5.25 (8.12), CL 3.5 (3.99), CW 2.33 (2.86). Eyes: AME $0.10(0.16)$, ALE 0.09 (0.14), PME 0.26 (0.33), PLE 0.23 (0.23). Row of eyes: AE 0.63 (0.79), PME 0.79 (0.94), PLE 1.03 (1.23). Sternum (length/width) $1.5 / 1.2(1.65 / 1.50)$. Labium (length/width) $0.46 / 0.46(0.50 / 0.53)$. AL 2.18 (4.51), AW 1.8 (3.46). Legs: Lengths of segments (femur + patella $/$ tibia + metatarsus + tarsus $=$ total length): Pedipalp 1.09+1.00+ $++1.06=3.15$, I $2.29+2.95+2.15+1.12=8.51$, II $2.29+2.83+2.17+1.09=$ 8.38 , III $2.26+2.60+2.40+1.06=8.32$, IV $2.83+3.43+3.26+1.43=10.95$ (Pedipalp 0.80+0.85+$+0.95=2.6$, I $2.65+3.15+2.05+1.00=8.85$, II $2.50+3.05+2.05+1.05=8.65$, III $2.45+2.90+2.30+1.05$ $=8.7$, IV 3.25+4.05+3.45+1.40=12.15).

Variation. Males (females) (range, mean \pm s.d.): TL $3.90-7.20,5.07 \pm 0.89 ; \mathrm{n}=11 ; \mathrm{CL} 2.10-3.60,2.73 \pm$ $0.44 ; \mathrm{n}=12 ; \mathrm{CW} 1.50-2.85,2.13 \pm 0.44 ; \mathrm{n}=12$ (TL $5.25-9.90,7.99 \pm 1.38 ;$ CL $2.70-4.20,3.75 \pm 0.40$; CW $2.10-3.30,3.00 \pm 0.34 ; n=17)$.

\section{Remarks}

McKay (1979b) considered A. impedita a subspecies of Trochosa expolita (L. Koch, 1877), Trochosa expolita impedita (Simon, 1909). However, a comparison of the holotype of $A$. impedita and the female syntypes of T. expolita (MHNT AR0824) clearly showed that these species are not congeneric. It is evident that McKay (1979b) misinterpreted the epigyne structure of the holotype of $A$. impedita. The presence of a basoembolic apophysis and the bifurcate median apophysis in the male pedipalp clearly identify this species as Artoria and it is here removed from the lycosine genus Trochosa.

\section{Distribution}

Western Australia (Figure 10).

\section{Artoria paroula Thorell, 1877 \\ Figures 11A-B, 12}

Artoria paroula Thorell, 1877: 531.- Thorell, 1892: 185; Bonnet, 1955: 751; Roewer, 1955: 233; Chrysanthus, 1967: 423, figures 68-69; Platnick, 1998: 550; Framenau, 2002: 223-224, figures $17 \mathrm{~A}-\mathrm{C}, 18$.

Artoria luwamata Barrion and Litsinger, 1995: 364365, figure 213.- Platnick, 1998: 550.

\section{Types}

Holotype male of Artoria paroula Thorell, 1877: Kandari, Selebes (= Sulawesi), Indonesia, $3^{\circ} 58^{\prime} \mathrm{S}$, $122^{\circ} 35^{\prime} \mathrm{E}, 1874, \mathrm{O}$. Beccari, MSNG. Examined.

Holotype male of Artoria luwamata Barrion and Litsinger, 1995: Real, Llavac Vill., Luzon Island, Quezon Province, Philippines, $4^{\circ} 39^{\prime} \mathrm{S}, 121^{\circ} 36^{\prime} \mathrm{E}, 19$ August 1985, A. T. Barrion, IRRI. Examined.

\section{Other material examined}

Northern Territory: 2 males, Annaburro, $12^{\circ} 54^{\prime} \mathrm{S}$, $131^{\circ} 40^{\prime} \mathrm{E}$, April 1997, T. B. Churchill, Natt, grid 1, trap 14, clay site (NTMAG A858); 1 female, Douglas Daly, 1350'S, $131^{\circ} 11^{\prime} \mathrm{E}, \mathrm{T}$. B. Churchill, April 1997 (NTMAG A857).
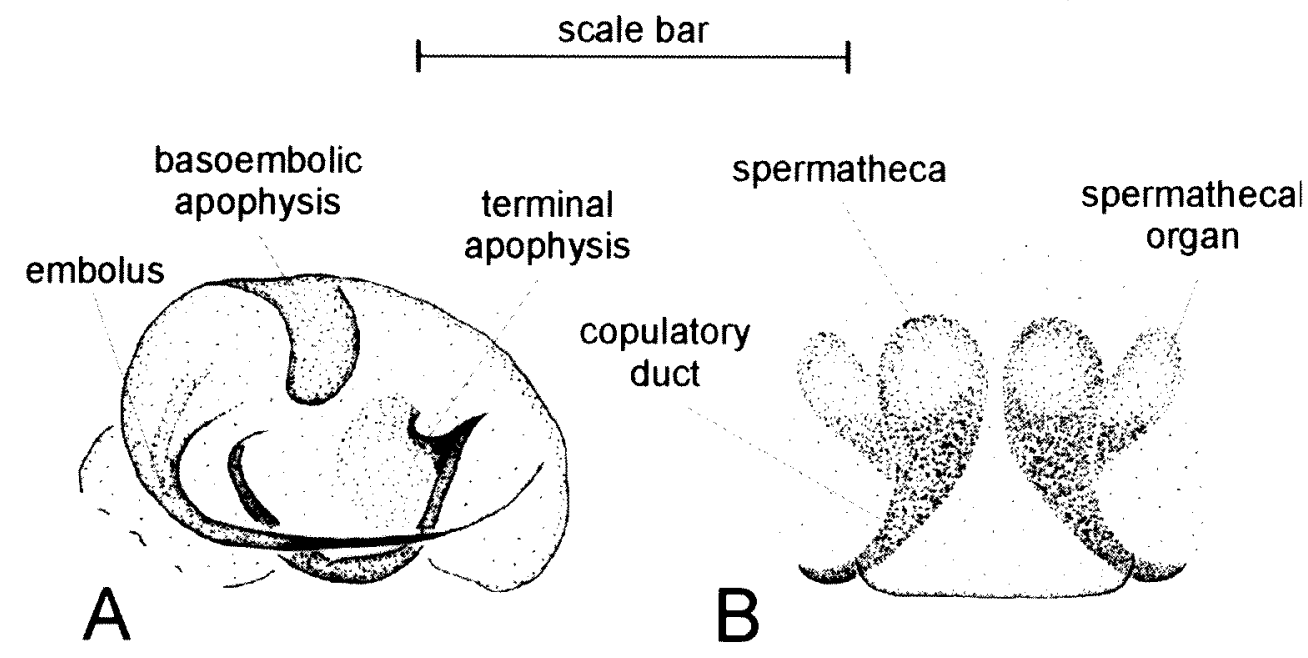

Figure 11 Artoria paroula Thorell, 1877, male (NTMAG A858 from Annaburro, Northern Territory): A - left pedipalp, apical part of bulbus. Female (NTMAG A857 from Douglas Daly, Nothern Territory): B - epigyne, ventral view. Scale bar: $A-0.22 \mathrm{~mm} ; B-0.20 \mathrm{~mm}$. 


\section{Description}

Male: The male of $A$. paroula was redescribed in detail by Framenau (2002), then known only from two males, the holotypes of $A$. parvula from Indonesia and its junior synonym $A$. luwamata from the Philippines. The collection of non-type material from Australia allowed the dissection of the male pedipalp and a detailed illustration of the apical section of the bulb. The embolus is slender resting in a groove formed by the terminal apophysis (Figure 11A).

Female (based on NTMAG A857). Carapace: Brown, with distinct yellow-brown submarginal bands; narrow yellow median band restricted to posterior half; black between eyes; indistinct grey radial pattern; few silver-white setae in eye region; long bristle between $\mathrm{AME}$; two very long bristles below AME. Sternum: Yellow; few brown bristles marginally. Labium: Light brown; front end white. Chelicerae: Yellow-brown; grey pigmentation frontally; few whitish setae; two retromarginal teeth, with the apical larger; one promarginal tooth. Epigyne (Figure 9B): Wide posterior lip with no visible sclerotization; spermathecae large, spermathecal organs large and visible laterally.
Abdomen: Uniformly dark olive-grey; covered with few brown setae; venter light olive-yellow; spinnerets yellow. Legs: Leg formula IV > I > III > II; light brown, indistinct annulations mainly on femora; spination of leg I: Femur: 3 dorsal, 1 apicoprolateral; tibia: 2 ventral pairs, 1 prolateroventral; metatarsus: 3 ventral pairs.

Measurements. Female (NTMAG 857): TL 2.52, CL 1.37, CW 0.99. Eyes: AME 0.06, ALE 0.04, PME 0.22, PLE 0.17. Row of eyes: AE 0.32, PME 0.60, PLE 0.57. Sternum (length/width) 0.66/0.54. Labium (length/ width) 0.20/0.22. AL 0.77, AW 1.03. Legs: Lengths of segments (femur + patella/tibia + metatarsus + tarsus $=$ total length): Pedipalp $0.43+0.46+-+0.34=$ 1.23 I $0.97+1.14+0.72+0.44=3.27$, II $0.89+1.00+0.66+0.43=2.98$, III $0.83+0.94+0.72+0.43$ $=2.92$ IV $1.26+1.57+1.32+0.57=4.72$.

Variation. Males (range, mean \pm s.d.): TL $2.70-$ $3.15,2.90 \pm 0.21$; CL $1.55-1.73,1.62 \pm 0.09$; CW 1.05 $-1.15,1.11 \pm 0.04 ; n=4$.

\section{Distribution}

Northern Territory (Figure 12); also in Indonesia and the Philippines.

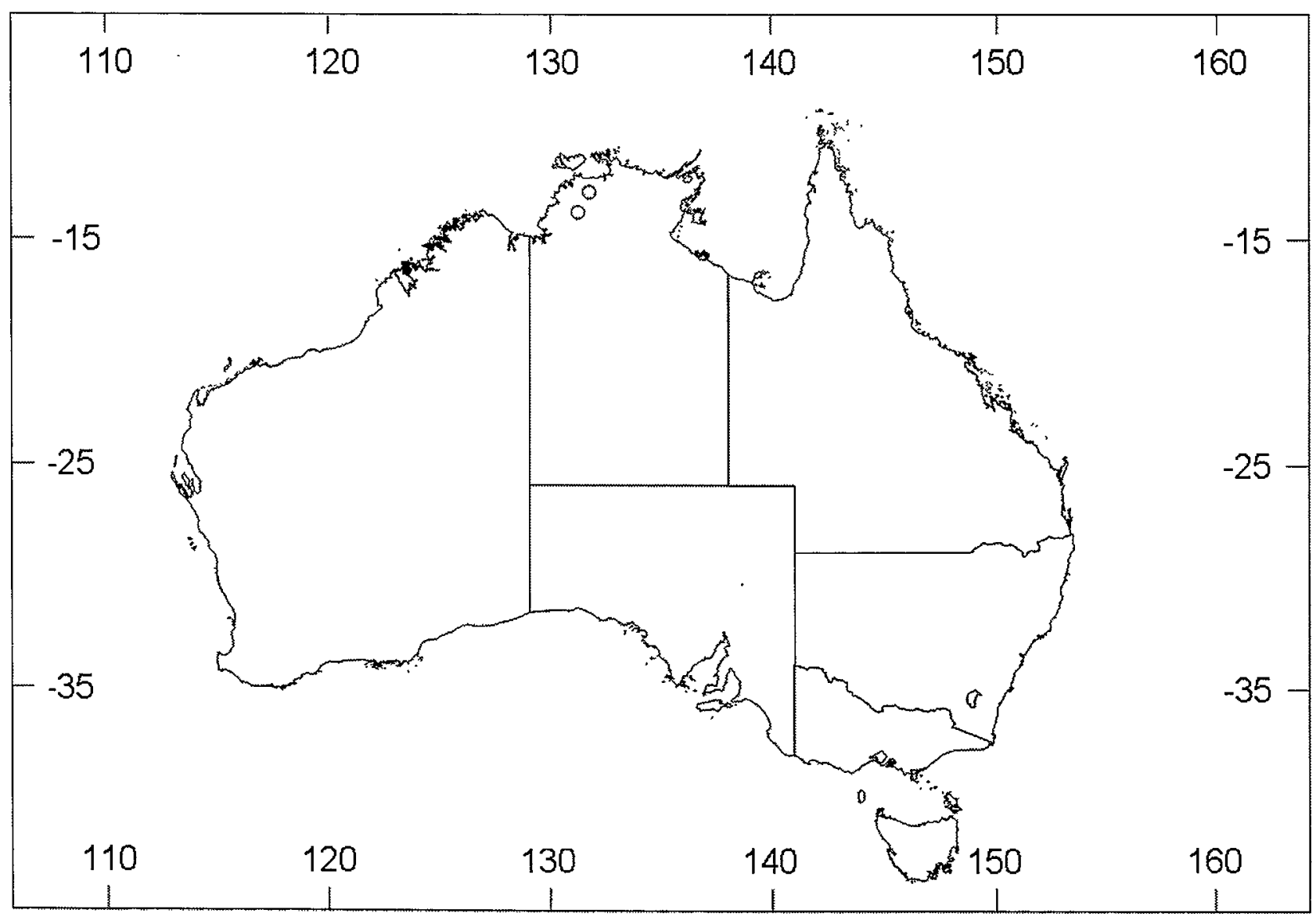

Figure 12 Records of Artoria paroula Thorell, 1877 in Australia. This species is also known from Indonesia and the Philippines. 


\section{Remarks}

The female described above has only been found in close proximity to a locality of males of $A$. paroula but not with them, however, it agrees very well in all somatic characters with these males. Therefore, I consider it the female of $A$. paroula, which is here described for the first time.

Artoria pruinosa (L. Koch, 1877), comb. nov.

Lycosa pruinosa L. Koch, 1877: 925-927, plate 80, figures 2, 2A; Rainbow, 1911: 271; McKay, 1985: 82.

Dingosa pruinosa (L. Koch).- Roewer, 1955: 240.

\section{Type}

Holotype male of Lycosa pruinosa L. Koch, 1877:

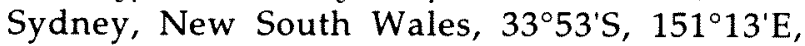
Bradley Collection, considered lost. Not examined.

\section{Remarks}

The holotype male of Lycosa pruinosa (L. Koch, 1877) from Sydney was part of the Bradley Collection and must be considered lost. The examination of the lycosid material of the AM did not reveal a species that I could confidently identify as L. pruinosa. A detailed examination of all Artoria material as part of a complete revision of this genus may disclose the identity of this species. However, Koch's (1877) illustration of the male pedipalp clearly shows the generic characters of the genus Artoria, in particular the apically directed median apophysis that is narrowly spoon-shaped. Previous placements in Lycosa and Dingosa are certainly erroneous, as both genera belong to the subfamily Lycosinae with a very different pedipalp structure. Consequently, this species is here transferred to Artoria.

\section{Artoria taeniifera Simon, 1909}

Figures $13 \mathrm{~A}-\mathrm{B}, 14$

Artoria taeniifera Simon, 1909: 193-194, figure 11.Rainbow, 1911: 275; Bonnet, 1955: 751; McKay, 1973: 380; McKay, 1985: 74; Moritz, 1992: 327; Framenau, 2002: 226-227, figures 21A-B, 22.

Artoriella taeniifera (Simon).- Roewer, 1955: 233; Roewer, 1960: 563.

Type

Holotype female of Artoria taeniifera Simon, 1909: Bunbury, Western Australia, 33 $20^{\circ} \mathrm{S}, 115^{\circ} 39^{\prime} \mathrm{E}$ W. Michaelsen, R. Hartmeyer ('Hamburger südwestaustralische Expedition'), Station 142, (Michaelsen and Hartmeyer (1907), from German: '24./25. July 1905, dunebush, coastland'), ZMB 10549. Examined.

\section{Other material examined}

New South Wales: 1 female, The Round Hill, $32^{\circ} 57^{\prime} \mathrm{S}, 1^{\circ} 6^{\circ} 09^{\prime} \mathrm{E}, 3$ March 1972, M. R. Gray (AM KS50283). Western Australia: 1 female, Leeman, $29^{\circ} 56^{\prime} \mathrm{S}, 114^{\circ} 58^{\prime} \mathrm{E}, 30$ August 1981, R. P. McMillan, Casuarina swamp (WAM T53538); 1 female with eggsac, Rossmoyne, $32^{\circ} 02^{\prime} 22^{\prime \prime} \mathrm{S}, 115^{\circ} 45^{\prime} 39^{\prime \prime} \mathrm{E}, 24$ October 1970, R. J. McKay (WAM 71/551); 1 female, 4 juv., Sues Bridge, 50km SW Nannup, $34^{\circ} 04^{\prime} \mathrm{S}$, $115^{\circ} 23^{\prime} \mathrm{E}, 26$ July 1980, S and J. Peck, SBP WA143, Marri log litter (WAM T55329).

\section{Description}

The holotype female of $A$. taeniifera was redescribed in detail by Framenau (2002). The presence of a number of other females in Australian collections allowed the dissection and illustration of the internal genitalia of this species. The epigyne forms an ovoid median septum with strongly sclerotized posterior lips (Figures 13A). The spermathecae are large and bulbous and the

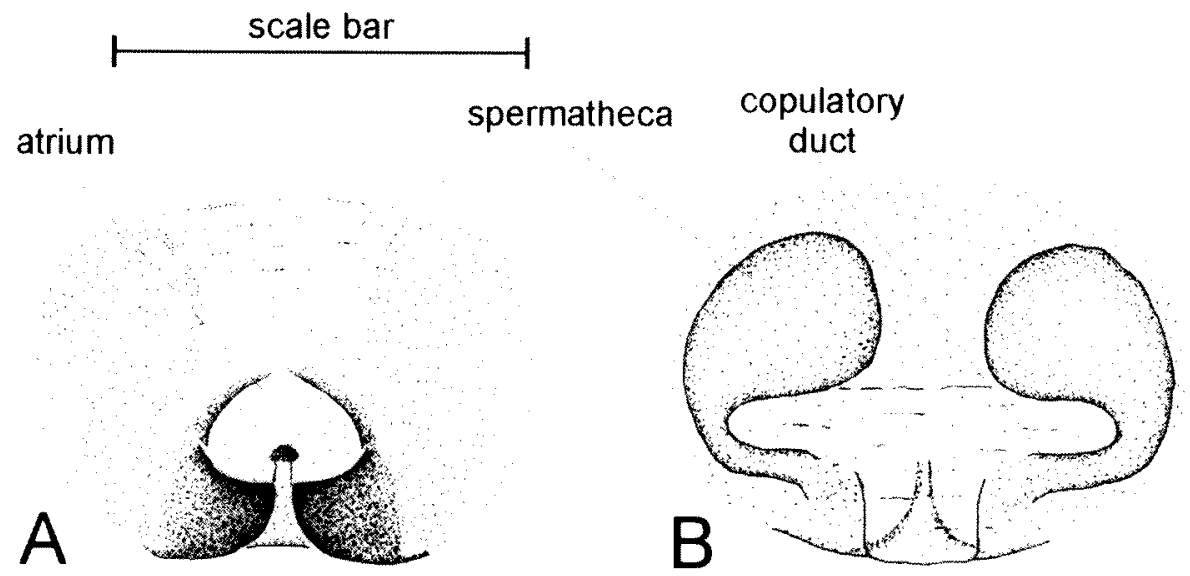

Figure 13 Artoria taeniifera Simon, 1909, female (WAM T55329 from Sues Bridge, Western Australia): A - epigyne, ventral view, B - epigyne, dorsal view. Scale bar: $0.39 \mathrm{~mm}$. 


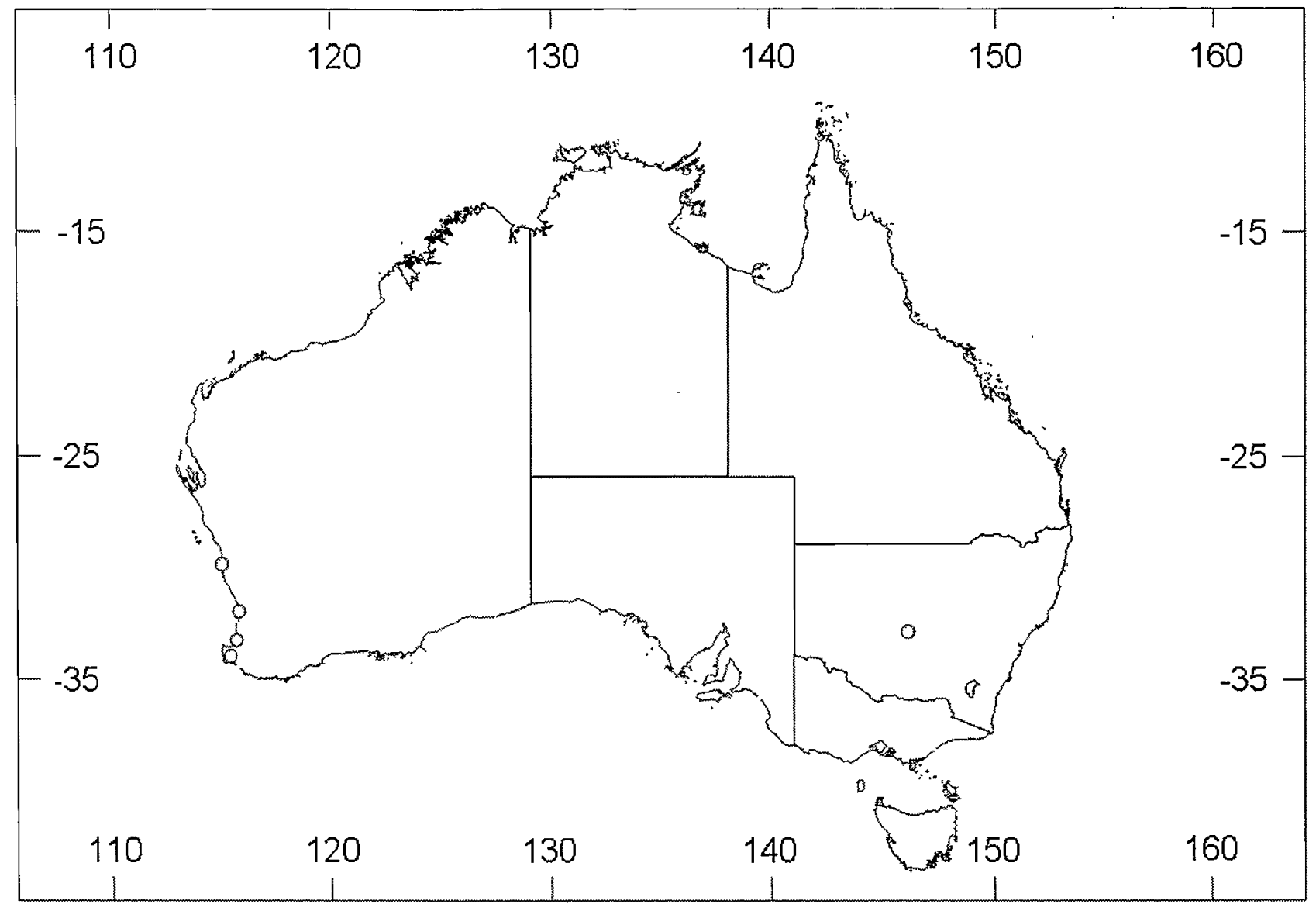

Figure 14 Records of Artoria taeniifera Simon, 1909.

copulatory ducts attach posterolaterally (Figure 13B).

Variation. The holotype displays an inverted colour pattern of the abdomen with a dark median band instead of a yellow lanceolate heartmark in comparison with all other known Artoria (see Framenau, 2002; figure 21A). This inverted pattern seems to be an artifact of its preservation, as all other females display the typical Artoria pattern, a light heart mark in the anterior half of the abdomen. Females (range, mean \pm s.d.): TL $4.95-7.65,6.39 \pm$ 1.17; CL 2.25-3.15, $2.64 \pm 0.33$; CW 1.65-2.40, 1.95 $\pm 0.28 ; n=5$.

\section{Distribution} 14).

Western Australia and New South Wales (Figure

\section{Updated distribution of Artoria in Australia}

Since the first review of the genus Artoria (Framenau 2002) a large amount of material has been examined in all the major collections in Australia. Therefore, new record maps are provided here to update the distribution of all species of Artoria in Australia (Figures 15, 16). For some species, range extensions are considerable. For example, $A$. avona, previously known only from the floodplain of the Avon River in East Gippsland
(Victoria), has now been found in considerable numbers in South Australia (Figure 15). Whereas most currently named Artoria are widespread, for example $A$. albopilata, $A$. flavimana and $A$. berenice, some have a very restricted distribution. Artoria gloriosa, for example, appears to be endemic to Lord Howe Island, and A. albopedipalpis is currently only known from riparian gravel banks in alpine floodplains in Victoria.

\section{ACKNOWLEDGEMENTS}

This study would not have been possible without the kind and generous support from the following individuals and their institutions: Graham Milledge and Mike Gray (AM), Bruce Halliday (ANIC), Janet Beccaloni (BMNH), Christine Rollard (MNHP), Pascal Leblanc (MNHT), Ken Walker, Peter Lillywhite, and Richard Marchant (MV), Owen Seeman and Rob Raven (QM), Lisa Joy Boutin (QVMAG), David Hirst (SAM), Liz Turner (TMAG), Mark Harvey and Julianne Waldock (WAM), Jason Dunlop and Shahin Nawai (ZMB), Alberto Barrion (IRRI), Gavin Dally (NTMAG), and Hieronymus Dastych (ZMH). I am in particular grateful to Tracey Churchill (Darwin) and Barbara Baehr Rob and Raven (Brisbane) for their hospitality during recent visits to the NTMAG and 


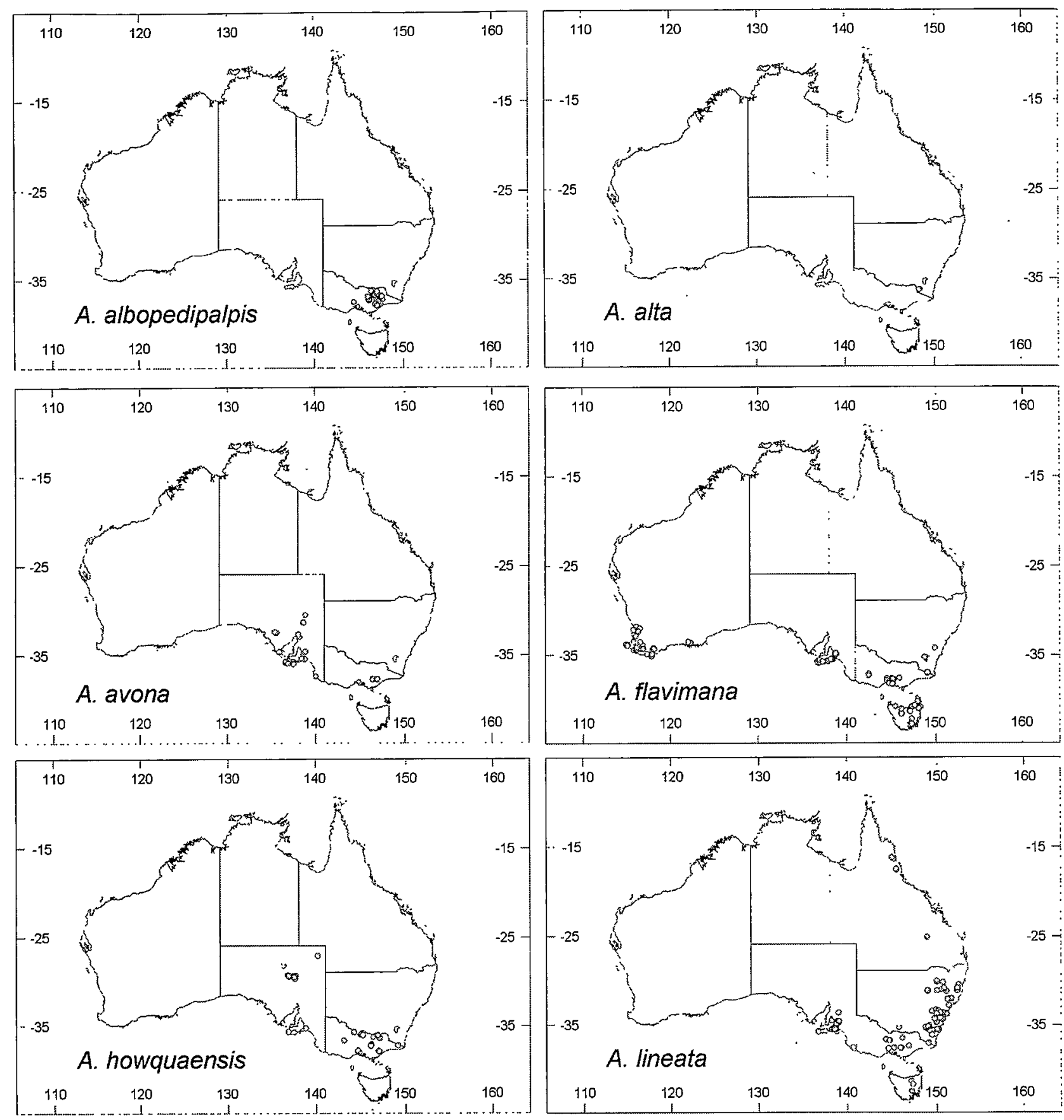

Figure 15 Records of A. albopedipalpis Framenau, 2002, A. alta Framenau, 2004, A. avona Framenau, 2002, A. flavimana Simon, 1909, A. howquaensis Framenau, 2002, and A. lineata (L. Koch, 1877).

QM. Melissa Thomas, Julianne Waldock and Mark Harvey provided comments on earlier drafts of the manuscript. The Australian Biological Resources Study (ABRS) provided funding for this project to Mark Harvey (WAM) and Andrew Austin (Adelaide University).

\section{REFERENCES}

Alderweireldt, M. and Jocqué, R. (1993). A redescription of Tricassa deserticola Simon, 1910, representing the Tricassinae, a new subfamily of wolf spiders (Araneae, Lycosidae). Belgian Journal of Zoology 123: 27-38.
Baehr, B. and Baehr, M. (1987). The Australian Hersiliidae (Arachnida: Araneae): Taxonomy, phylogeny, zoogeography. Invertebrate Taxonomy 1: $351-437$.

Barrion, A.T. and Litsinger, J.A. (1995). Riceland Spiders of South and Southeast Asia. CAB International, Wallingford, pp. 1-736.

Berland, L. (1938). Araignées des Nouvelles-Hebridés. Annales de la Société Entomologique de France 107: 121190.

Bonnet, P. (1955). Bibliographia Araneorum, Tome II. Douladoure, Toulouse, pp. 1-918.

Bonnet, P. (1957). Bibliographia Araneorum, Tome II (3me partie: G-M), Douladoure, Toulouse, pp. 1926-3026. 


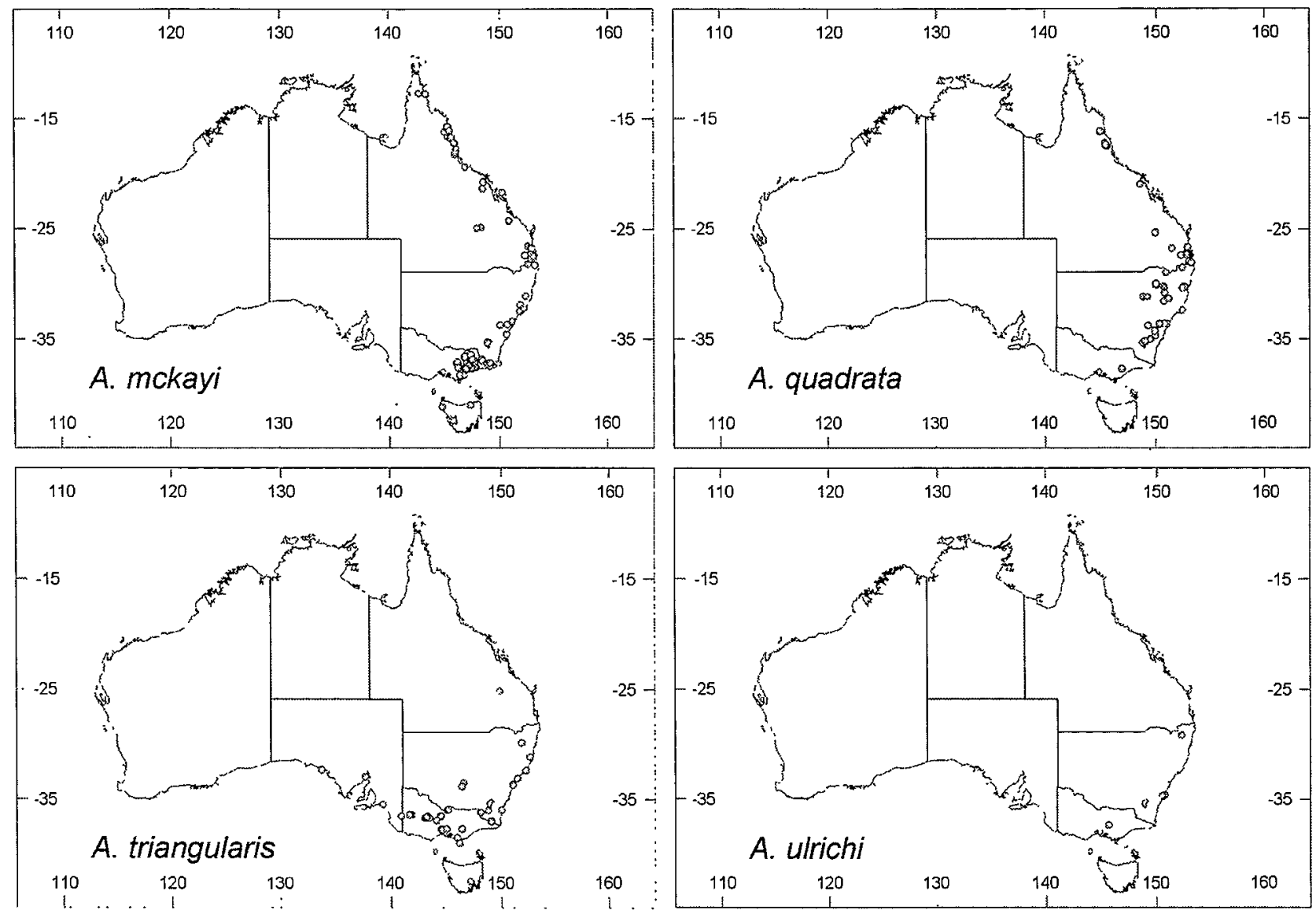

Figure 16 Records of A. mckayi Framenau, 2002, A. quadrata Framenau, 2002, A. triangularis Framenau, 2002 , and A. ulrichi Framenau, 2002

Chrysanthus, F. (1967). Spiders from South New Guinea VIII. Nova Guinea, Zoology 37: 401-426.

Court, D.J. and Forster, R.R. (1988). The spiders of New Zealand. Part VI. Araneidae-Araneinae. Otago Museum Bulletin 6: 68-124.

Dondale, C.D. (1986). The subfamilies of wolf spiders (Araneae: Lycosidae). Actas X Congreso Internacional de Aracnología, Jaca, España 1: 327-332.

Forster, R.R. (1967). The spiders of New Zealand. Part I. Otago Museum Bulletin 1: 1-124.

Framenau, V.W. (2002). Review of the wolf spider genus Artoria Thorell (Araneae, Lycosidae). Invertebrate Systematics 16: 209-235.

Framenau, V.W. (2004) [imprint date 2003]. Two alpine wolf spiders of Australia: Artoria alta sp. nov., and the male of Lycosa musgravei McKay, 1974 (Araneae, Lycosidae). Proceedings of the Royal Society of Victoria 115: 27-34.

Framenau, V.W., Manderbach, R. and Baehr, M. (2002). Riparian gravel banks of upland and lowland rivers in Victoria (south-east Australia): arthropod community structure and life-history patterns along a longitudinal gradient. Australian Journal of Zoology 50: 103-123.

Hogg, H.R. (1900). A contribution to our knowledge of the spiders of Victoria; including some new species and genera. Proceedings of the Royal Society of Victoria 8: 67-123.

Koch, L. (1875). Aegyptische und abyssinische Arachniden gesammelt von Herrn C. Jickeli. Bauer and Raspe, Nürnberg, pp. 1-96.

Koch, L. (1876) Die Arachniden Australiens, nach der Natur beschrieben und abgebildet. Bauer and Raspe, Nürnberg, pp. 741-888.

Koch, L. (1877) Die Arachniden Australiens, nach der Natur beschrieben und abgebildet. Bauer and Raspe, Nürnberg, pp. 889-968.

Koch, L. (1878) Die Arachniden Australiens, nach der Natur beschrieben und abgebildet. Bauer and Raspe, Nürnberg, pp. 969-1044.

McKay, R.J. (1973). The wolf spiders of Australia (Araneae: Lycosidae): 1. The bicolor group. Memoirs of the Queensland Museum 16: 375-398.

McKay, R. J. (1979a). The wolf spiders of Australia (Araneae: Lycosidae): 11. A new species from Lord Howe Island. Memoirs of the Queensland Museum 19: 237-240.

McKay, R.J. (1979b). The wolf spiders of Australia (Araneae: Lycosidae): 13. The genus Trochosa. Memoirs of the Queensland Museum 19: 277-298.

McKay, R.J. (1985). Lycosidae. In D.W. Walton, ed. Zoological Catalogue of Australia, Vol. 3. Arachnida, Mygalomorphae, Araneomorphae in Part, Pseudoscorpionida, Amblypygida, Palpigradi. Canberra: Australian Government Publishing Service, pp. 7388.

Michaelsen, W. and Hartmeyer, R. (1907). Reisebericht. In Michaelson, W. and Hartmeyer, R. eds. Die Fauna 
Südwest-Australiens. Ergebnisse der Hamburger sïdwestaustralischen Forschungsreise 1905. Gustav Fischer, Jena, pp. 1-116.

Moritz, M. (1992). Die Typen der Arachniden-Sammlung des Zoologischen Museums Berlin. X. Araneae: Lycosidae. Mitteilungen des Zoologischen Museums Berlin 68: 309-329.

Platnick, N.I. (1989). Advances in Spider Taxonomy, 19811987. Manchester University Press, Manchester. Pp. $1-673$.

Platnick, N.I. (1998) [imprint date 1997]. Advances in Spider Taxonomy, 1992-1995. With Redescriptions 19401980. New York Entomological Society in association with the American Museum of Natural History, New York, pp. 1-976

Platnick, N.I. (2004). The World Spider Catalog, Version $5.0 \mathrm{http}: / /$ research.amnh.org/entomology/spiders/ catalog/INTRO1.html. American Museum of Natural History.

Rack, G. (1961). Die Entomologischen Sammlungen des Zoologischen Staatsinstituts und Zoologischen Museums Hamburg. II. Teil Chelicerata II: Araneae. Mitteilungen des Hamburgischen Zoologischen Museums und Instituts 59: 1-60.

Rainbow, W.J. (1911). A census of Australian Araneidae. Records of the Australian Museum 9: 107-319.

Rainbow, W.J. (1920). Arachnida from Lord Howe and Norfolk Islands. Records of the South Australian Museum 1: 229-272.

Roewer, C.F. (1951). Neue Namen einiger Araneen-Arten. Abhandlungen herausgegeben vom Naturwissenschaftlichen Verein zu Bremen 32: 437-456.

Roewer, C.F. (1955) [imprint date 1954]. Katalog der Araneae von 1758 bis 1940. Vol. 2a. Institut Royal des Sciences Naturelles de Belgique, Bruxelles, pp. 1-923.

Roewer, C. F. (1960) [imprint date 1959]. Araneae Lycosiformae II (Lycosidae) (Fortsetzung und Schluss). Exploration du Parc National de l'Upemba Mission GF de Witte 55: 519-1040.
Simon, E. (1909). Araneae, 2me partie. In Michaelson, W. and Hartmeyer, R. eds. Die Fauna Südwest-Australiens. Ergebnisse der Hamburger siidwest-australischen Forschungsreise 1905. Gustav Fischer, Jena, pp. 155212.

Strand, E. (1909). Spinnentiere von Südafrika und einigen Inseln gesammelt bei der deutschen SüdpolarExpedition. In Deutsche Siidpolar-Expedition 1901-1905. Berlin, 10: 541-596.

Sundevall, J. C. (1833). Conspectus Arachnidum. C. F. Berling, Lund (Sweden), 1-39.

Thorell, T. (1877). Studi sui Ragni Malési e Papuani. Annali di Museo Civico di Storia Naturale 'Giacomo Doria', Genova 10: 341-634.

Thorell, T. (1892). Studi sur Ragni Malési e Papuani. Parte IV. Volume II. Annali di Museo Civico di Storia Naturale 'Giacomo Doria', Genova 31: 1-490.

Urquhart, A.T. (1893). On new species of Tasmanian Araneae. Papers and Proceedings of the Royal Society of Tasmania 1892: 94-130.

Vink, C.J. (2002). Fauna of New Zealand. Number 44. Lycosidae (Arachnida: Araneae). Manaaki Whenua Press, Lincoln (New Zealand), pp. 1-94.

Vink, C.J., Mitchell, A.D. and Paterson, A.M. (2002). A preliminary molecular analysis of phylogenetic relationships of Australasian wolf spider genera (Araneae, Lycosidae). Journal of Arachnology 30: 227237.

Zyuzin, A.A. (1985). Generic and subfamilial criteria in the systematics of the spider family Lycosidae (Aranei), with the description of a new genus and two new subfamilies. Proceedings of the Zoological Institute Leningrad, USSR Academy of Science 139: 4051.

Zyuzin, A.A. (1993). Studies on the wolf spiders (Araneae: Lycosidae). I. A new genus and new species from Kazakhstan, with comments on the Lycosinae. Memoirs of the Queensland Museum 33: 693700.

Manuscript received 22 June 2004; accepted 17 December 2004 